TITLE:

\title{
Education, organizational commitment, and rewards within Japanese manufacturing companies in China
}

$\operatorname{AUTHOR}(S)$ :

Kokubun, Keisuke

\section{CITATION:}

Kokubun, Keisuke. Education, organizational commitment, and rewards within Japanese manufacturing companies in China. Employee Relations 2018, 40(3): 458-485

\section{ISSUE DATE:}

2018

URL:

http://hdl.handle.net/2433/255896

\section{RIGHT:}

(c) Emerald Publishing Limited. This AAM is provided for your own personal use only. It may not be used for resale, reprinting, systematic distribution, emailing, or for any other commercial purpose without the permission of the publisher.; この論文は出版社版でありません。引用の際には出版社版をご確認ご利用ください。; This is not the published version. Please cite only the published version. 
Education, organizational commitment, and rewards within Japanese manufacturing companies in China

Keisuke Kokubun

Kyoto University

Kokubun, K. (2018), "Education, organizational commitment, and rewards within Japanese manufacturing companies in China", Employee Relations, Vol. 40 No. 3, pp. 458-485. https://doi.org/10.1108/ER-12-2016-0246 
Education, organizational commitment, and rewards within Japanese manufacturing companies in China

\begin{abstract}
Purpose - The purpose of this paper is to investigate the relationship between organizational commitment and extrinsic, intrinsic, and social rewards, among employees who work for Japanese manufacturing companies in China.

Design/methodology/approach -Hierarchical regression analysis was utilized to examine survey data obtained from 27,854 employees, who work for 64 Japanese manufacturing companies in China.

Findings - The findings demonstrate that the variables measuring extrinsic, social, and intrinsic rewards were strongly related to organizational commitment, suggesting that the antecedents of organizational commitment in Japanese companies are different from those in other kinds of corporations in China and the West. A further comparison between university graduates and other employees showed that for graduates, extrinsic and intrinsic rewards had a stronger influence on organizational commitment than social rewards, compared to non-graduates.

Research limitations/implications - This study used self-report data from individual respondents, which may have resulted in common method bias. Future research might consider including supervisor-rated scales to strengthen the study design and reduce common method bias.

Practical implications - As Japanese companies in China have both Western and Chinese characteristics, they often utilize balanced human resources management (HRM) practices. To enhance their employees' organizational commitment (OC), especially those with less formal education, it is most effective to focus not only on some particular rewards but also on more varieties of rewards. However, balanced HRM may not be equally effective for enhancing the $\mathrm{OC}$ of university graduates, who prefer to obtain more extrinsic and intrinsic rewards and fewer social rewards. As Japanese companies are sometimes said to be less attractive workplaces, especially for university graduates, the results of this study could help HR professionals revise their HRM strategies and employ workers who can contribute to their Chinese branches on a long-term basis.

Originality/value - This research investigates how employees of Japanese companies in China could have higher organizational commitment, by focusing on the difference between university graduates and non-graduates and utilizing a large volume of their opinion data.

Paper type Research paper
\end{abstract}

Keywords China; exploratory factor analysis; organizational commitment; Japanese companies; rewards

\title{
Introduction
}

Among developing countries, China is the largest recipient of foreign direct investment (FDI) and has the largest number of employees who work for foreign companies (UNCTAD, 2010). In 2004, approximately 24 million workers (3\% of China's total employment) were employed by foreign companies in China (UNCTAD, 2004). Japanese companies continue to benefit from China's growth and remain one of the leading investors in China, accounting for $6.5 \%$ of Japan's total FDI in 2015 (JETRO, 2016b). In response to the yen's appreciation against the dollar following the 1985 Plaza Accord, Japanese investment in China has shown a remarkable increase: it accounted for $6.0 \%$ of the total effective FDI in 2013 and Japan became China's third largest source of foreign capital, following Hong Kong and Singapore (JETRO, 2016a). The number of Japanese companies located in China at the end of 2012 was 23,094, which accounted for the highest share $(7.9 \%)$ of total foreign companies located in China (CJCCl, 2016). Similarly, 1.62 million employees worked for Japanese companies in China in 2015, which was $40.5 \%$ of total employees of Japanese companies across Asia (METI, 2016). 
However, foreign companies in China face a major problem: they must determine how to manage and retain the local employees. Japanese companies have significant problems in this regard, both in terms of high employee turnover and of competing for the best employees. Surveys have indicated that Japanese companies in China rarely if ever rank among the most popular employers, and are even frequently listed among foreign companies that people least want to work for (Zhang, 2003). These difficulties may have to do with a decrease in their rank and share in the total effective FDI in this country, from third $(6.0 \%)$ in 2013 to fifth $(2.5 \%)$ in 2015 . During this period they were outstripped by both Taiwan and Korea (JETRO, 2016a).

Given this situation, it is necessary to determine how Japanese companies can reduce their employee turnover rates or attract the best employees in China. To meet these goals, this study analyzes antecedents of organizational commitment (OC) and how those antecedents differ between university graduates and other workers who are employed by Japanese manufacturing firms in China. Here, OC is defined as an employee's state of being committed to assist in the achievement of the organization's goals, and involves the employee's levels of identification, involvement, and loyalty (Caught et al., 2000). OC is seen as a prime explanation for why some people desire to remain employed while others do not (Allen \& Meyer, 1990; Mowday et al., 1982; Peyyer et al., 2010; Steers, 1977) or why some have a high work performance while others do not (Meyer et al., 2002; Phipps et al., 2013). Likewise, this study focuses on university graduates because previous research indicated that the future growth of Japanese multinational corporations (MNCs) will depend on their international human resource management (HRM) efforts to attract, develop, motivate, and retain the best and brightest local talents (Furusawa et al., 2016). As described below, however, Japanese companies have largely failed to attract such laborers. The study may also contribute to the creation of jobs for those who cannot find work due to a labor market mismatch, by attracting more talent to Japanese as well as other foreign companies who need high-OC employees with appropriate skills. In this context, a labor market mismatch is the difference between the talents a company wants and those a job seeker has, and has become more serious due to the economic slowdown and an increase in higher education opportunities (JRI, 2008).

\section{Literature Review Japanese companies in China}

Japanese companies have come up with a distinct human resource management (HRM) model, characterized by high levels of commitment, loyalty, productivity, and product quality, along with lower rates of turnover, absenteeism, and industrial conflict (Colignon et al., 2007). These features of the Japanese manufacturing workplace are said to be strongly present in Japanese overseas subsidiaries, and may be even more appropriate for countries that are developing economically (Wasti, 1998). Accordingly, several studies have investigated if and how Japanese companies can transfer this model to their overseas operations (e.g., Komai, 1989; Konomoto, 2000). Along similar lines, elements of the "iron rice-bowl" widely observed in Chinese society, such as secure employment or an emphasis on seniority, seem to resemble the elements of Japanese management, even though Japanese companies are often included in the Western group among "foreign companies" in China.

However, it was found that Japanese companies tend to rely much more heavily on expatriate managers from Japan in their foreign subsidiaries, especially in top management positions, compared to European and US companies (Pudelko \& Tenzer, 2013). These staffing policies have often been described as overly ethnocentric (Black \& Morrison, 2010; Wong, 2010) because host-country nationals (HCNs) in the subsidiaries were usually excluded from senior-level promotion opportunities and managerial training programs. In consequence, highly qualified and ambitious $\mathrm{HCNs}$ have not been attracted to Japanese employers (Froese \& Kishi, 2013).

In fact, a recent survey of more than 2,000 university students across Asia 
showed that Japanese MNCs were much less attractive than Western or domestic employers. Especially in countries affected by historical conflicts with Japan, such as China and Korea, only $2 \%$ of respondents were interested in working for a Japanese MNC (Froese \& Kishi, 2013). Likewise, Yu and Meyer-Ohle (2008) revealed that employees who worked for Japanese companies in China had more complaints than those who worked for Western companies, based on interview data. Japanese expatriates also reported particular management and adjustment difficulties in China (Furusawa \& Brewster, 2016). These studies indicate that while Japanese expatriates may be able to manage low-skilled workers such as factory workers, they lack the skills to manage highly-skilled employees such as university graduates (Sekiguchi et al., 2016).

Another study compared separation rates in Japanese and Western companies in Shanghai; the average Japanese rate $(15.2 \%)$ was more than twice the Western rate $(6.3 \%)$. Among specialists and technical staff, the Japanese separation rate reached $30 \%$ (RMS, 2012). Such a high separation rate in Japanese affiliates is sometimes attributed to their inadequate localization and insufficient communication between Chinese staffs and Japanese expatriates who are replaced every 3 to 4 years (Wan, 2009). In line with this finding, another previous survey revealed that Japanese managers in China received poorer evaluations from their subordinates than local managers did, especially on job performance, leadership, and capability of managing subordinates (Shiraki, 2012).

In spite of these blemishes, Japanese MNEs rely much more on parent-country nationals than their Western counterparts do (Tungli \& Peiperl, 2009; Ando, 2014). Therefore, local employees in foreign subsidiaries have not been given decision-making authority (Yoshihara, 1996) or promotion opportunities (Legewie, 2002) in Japanese companies. As international HRM for Japanese MNCs has been almost synonymous with the management of Japanese expatriates and host-country nationals have not been treated as potential international managers by the headquarters, the low level of normative integration might have generated mutual distrust between Japanese expatriates and local managers (Furusawa et al., 2016).

Based on these findings, the HRM of Japanese companies may not be fully effective for enhancing employees' $\mathrm{OC}$, at least in particular groups such as university graduates who have confidence in their skills and have more opportunities to work directly with Japanese expatriates, although it might be more effective for general employees in China. If these assertions are true, supervisors in Japanese companies in China may face some barriers to providing university-graduate employees with appropriate support which could be perceived as rewards worth reciprocating. Of course, the supervisors are not exclusively Japanese expatriates, but even the Chinese managers may be influenced by Japanese HRM. More importantly, they may vary in professional quality if the company couldn't attract skilled managers or educate the managers they can attract.

\section{Organizational rewards in China}

Barrett and O'Connell (2001) argued that employees may view some human resource practices as a reward. Hence, there is growing evidence to suggest that organizations can enhance the commitment of their workforce through the provision of organizational rewards (Newman et al., 2011). This research is based on social exchange theory, which supposes that when an individual is happy with the rewards provided by his or her organization, he or she will reciprocate by developing positive attitudes towards the organization, such as higher levels of commitment (Haar \& Spell, 2004). For example, it was shown that enhancement of OC brings lower turnover intention in the West (Steers, 1977; Peryer et al., 2010). However, despite tremendous research on OC (Meyer et al., 2002), there is little research on $O C$ and its antecedents in non-Western countries in general, and China in particular (Chen \& Francesco, 2000). Furthermore, it is unclear how different categories of organizational rewards might influence organizational commitment in Japanese companies in these countries.

This study aims to gain a deeper understanding into the different effects of 
extrinsic, social, and intrinsic rewards on the development of the OC of employees who work for Japanese companies in China. Porter and Lawler (1968) defined intrinsic rewards as the satisfaction that a person derives from doing a job and extrinsic rewards as tangible benefits obtained as a result of doing that job, such as pay and promotions. On the other hand, according to Mottaz (1985) social rewards are derived from interpersonal relationships with colleagues and supervisors. Previous work has found different valuation of these rewards: 1) intrinsic rewards have a greater impact on the $\mathrm{OC}$ of employees in the West than extrinsic or social rewards (Eby et al., 1999; Malhotra et al., 2007; O'Reilly \& Caldwell, 1980), while 2) extrinsic and social rewards have a greater impact on the OC of Chinese employees than intrinsic rewards (Miao et al., 2013; Newman \& Sheikh, 2012).

Given Hofstede's (1980) point that the culture of a country changes as its economy develops, this difference between Western and Chinese employees might be attributed not only to geographical features such as the West and the East but also to the economic stage in which each country is placed. Furthermore, Boyacigiller and Adler (1991) argued that the commitment of employees with collectivist values may arise from ties with managers, owners, and co-workers, whereas the commitment of employees with an individualist orientation may be due to the job itself or the compensation system. If these assertions are true, since Western countries are overall more developed than others and their employees are more individualistic, intrinsic rewards may accordingly be more important for OC. On the other hand, if we assume that China is less developed than Western countries and Chinese employees are less individualistic, social rewards may accordingly be more important for OC. Because the economy of China is still in transition and most employees must work to survive, extrinsic rewards are more important to Chinese employees' OC despite its collectivist culture.

However, a study conducted in South Africa, which at 6,483 US\$ GDP per capita in 2014 is at an economic stage close to China at 7,590 US\$ GDP per capita (World Bank, 2016), also obtained a result which should be categorized in group 1: intrinsic rewards are more associated with OC than extrinsic and social rewards (Nujjoo \& Meyer, 2012). This could be explained by the particular characteristics of the sample used in this study. The majority of participants were relatively highly-educated employees who had at least obtained a first diploma or degree. This indicates that an employee with a strong educational background in a developing country may have a mindset similar to a general employee in the West, and accordingly is more individualistic than others in the same country.

Supposing that such a relationship between economic or educational level and collectivistic or individualistic culture can be applicable worldwide, how can we identify effective rewards for enhancing $O C$ in Japanese companies located in China? Their employees are all Chinese irrespective of the employer's country of origin, and are considered to share some of the same characteristics whether they work for Japanese or other kind of corporations. Actually, Adler (1986) suggested that national culture has a greater impact on employees than does their organization's culture. In this sense, it is reasonable to assume that extrinsic and social rewards in Japanese companies are as much associated with $\mathrm{OC}$ as in other kind of corporations in China, in line with group 2 . In addition, Japanese companies may reasonably adapt to Chinese collectivism, because a company in Japan is considered to be a second family which encourages intensive socialization (Jackson \& Tomioka, 2004) and requires managers to be closely involved with a work group (Whitney, 1994), even though recent changes in Japanese management have departed from this model due to economic stagnation and the influence of globalization (Haghirian, 2010).

On the other hand, as Japan is a developed country and is considered to be accustomed to more sophisticated HRM than developing countries, Japanese employees also associate intrinsic rewards with $\mathrm{OC}$, in line with group 1. In addition, previous research suggests that individualism could be increasing in China (Yan, 2009), and that such a trend is likely to be most evident in more economically developed parts of the country (Gamble \& 
Tian, 2015; Ralston et al., 2008). Accordingly, intrinsic, extrinsic, and social rewards are all assumed to have positive effects on OC in Japanese companies in China. The present study is the first to test whether this assumption is true, and should help advise managers who work for companies in China as to what strategies are most likely to foster high levels of $\mathrm{OC}$ amongst their employees.

\section{Extrinsic rewards \\ Benefit satisfaction}

The provision of extrinsic benefits should lead the employee to reciprocate by exhibiting higher levels of OC. Empirical work in private sector organizations in the West is generally supportive of this pattern (Mottaz, 1988; Loscocco, 1990; Williamson et al., 2009), although some work finds contradictory evidence (Malhorta et al., 2007). Recent work also suggests that Chinese employees typically rank extrinsic benefits highly in comparison with intrinsic factors (Chiu et al., 2002; Newman \& Sheikh, 2012). This leads us to the following hypothesis:

Hypothesis 1: Benefit satisfaction is positively related to OC.

\section{Fatigue}

A number of studies demonstrate that exhausted workers exhibit lower levels of $O C$ and may eventually seek employment elsewhere (Lee \& Ashforth, 1996; Wright \& Cropanzano, 1998). Since this argument is ongoing, it is helpful to check the relationship between emotional exhaustion and OC in Japanese companies in China. This leads us to the following hypothesis:

Hypothesis 2: Fatigue is negatively related to OC.

\section{Social rewards \\ Supervisor support}

Empirical studies have provided evidence that perceptions of supervisory support positively affect employees' motivation and OC (Eisenberger et al., 1986; Mottaz, 1988). Recent work conducted in Chinese organizations demonstrates a strong relationship between supervisor support and OC, too (He et al., 2011; Miao et al., 2013; Nazir et al., 2016; Newman \& Sheikh, 2012; Wang, 2008). However, recent empirical work on private sector employees in the UK provides limited support for such assertions (Malhorta et al., 2007). This difference may arise from the fact that supervisors have a greater influence on the work activities of their subordinates in Chinese organizations than in the West, due to a cultural context in which there is respect for seniority, strict hierarchies in the workplace, and limited subordinate participation in decision-making (Chan et al., 2006; Cheng et al., 2003; Chen et al., 2002). This leads us to the following hypothesis:

Hypothesis 3: Supervisor support is positively related to OC.

\section{Co-worker support}

As it is an important channel for the dissemination of workplace knowledge and newcomer socialization into the organizational culture (Korczynski et al., 2000), the provision of support by co-workers should engender greater feelings of emotional attachment to the organization (Mottaz, 1988). Empirical work typically confirms a positive relationship between co-worker support and the OC of Western employees (Chiaburu \& Harrison, 2008; Self et al., 2005; Steijn \& Leisink, 2006). However, some recent work on Chinese employees in the private sector finds no evidence of such a relationship (Newman \& Sheikh, 2012; Wang, 2008) or that there is only a marginally significant influence (He et al., 2011), while another study on Chinese employees in the public sector finds there is a strong relationship (Miao et al., 2013). Although Japanese companies belong to the private sector in China, they have an organizational setting in which there are close-knit relationships between individuals, which is similarly observed in the Chinese public sector characterized by the "iron rice-bowl." This leads us to the following hypothesis: 
Hypothesis 4: Co-worker support is positively related to OC.

\section{Intrinsic rewards \\ Autonomy}

Autonomy is the degree to which employees are allowed freedom, independence, and discretionary powers when performing their job tasks and responsibilities (Sims et al., 1976). The more autonomy an employee has about what, when, and how to do work, the more he/she would feel a sense of responsibility for the job tasks, and feel needed in the workplace, thus engendering high levels of OC (Williamson et al., 2009). Empirical findings generally support such assertions in organizations in the West (Eby et al., 1999; Malhorta et al., 2007; Steijn \& Leisink, 2006). Likewise, recent work conducted in Chinese organizations demonstrates a strong relationship between autonomy and OC (Chen \& Aryee, 2007; Froese \& Xiao, 2012; Miao et al., 2013; Nazir et al., 2016; Newman \& Sheikh, 2012). This leads us to the following hypothesis:

Hypothesis 5: Autonomy is positively related to OC.

\section{Training provision}

The greater the sense of debt incurred during the training program, the more an employee becomes committed and devoted to the organization (Barrett and O'Connell, 2001). Specifically, the employees that viewed training as the most relevant to their current jobs were able to attain more positive commitment outcomes and had less intention to quit (Burke, 1995). Some findings from empirical work on employees in the West are supportive of a link between training provision and OC (Bartlett, 2001; Owens, 2006; Wayne et al., 1997), but some other studies found an insignificant relationship (Shore \& Barksdate, 1998) or a significant but negative relationship (Smeenk et al., 2006). The reasons for such mixed results may partly be because of market imperfection in which a company is not always successful in employing a person whose skills are compatible to what the company needs. In this setting, training will not be fully effective to enlarge an employee's skills and cause his/her reciprocity. Another reason might be that skills obtained through training are sometimes not specific to a company but general and applicable elsewhere. In this setting, a company may not fully induce an employee's OC (Becker, 1993).

In the Chinese setting, Newman et al. (2011) found a significant impact of training on the OC of employees working for multinational enterprises in China. On the other hand, Miao et al. (2013) found no significant relationship between training and OC in the public sector in China. In the Chinese public sector, political loyalty is more important to career progression than professional competence and training provision is unlikely to lead to higher levels of commitment, especially amongst employees with a limited connection to the Communist Party (Miao et al., 2013). As Japanese companies seemingly have a different culture from the public sector on this point, provision of training should be as effective to enhance OC as in most companies in the private sector. This leads us to the following hypothesis:

Hypothesis 6: Training is positively related to OC.

\section{Role clarity}

Role clarity is defined as the extent to which an employee knows what is expected of him/her for adequate performance of his/her tasks and job responsibilities (Rizzo et al., 1970). Role clarity would enhance a sense of felt responsibility and as such would bring about an increase in OC among employees (Gregersen \& Black, 1996). In both the West and China, empirical work on private sector employees typically finds a strong relationship between role clarity and organizational commitment (Mathieu \& Zajac, 1990; Newman \& Sheikh, 2012), although another study on public sector employees in China finds no significant relationship between them (Miao et al., 2013). This leads us to the following hypothesis:

Hypothesis 7: Role clarity is positively related to OC. 


\section{Comparative importance of rewards}

It is assumed that Japanese companies in China share characteristics of both Western and Chinese corporations, as discussed above. Accordingly, we expect that intrinsic rewards will be as much associated with $O C$ as in the West, whereas social rewards will be as much associated with $O C$ as in other kinds of corporations in China. On the other hand, we expect extrinsic rewards to be less associated with OC than other rewards, as the respondents in the sample work for Japanese companies where employees' lives are more secure and it is less necessary to work for sustenance. This leads us to the following hypothesis:

Hypothesis 8: Social and intrinsic rewards are positively related to OC, to the same extent. However, they are more significantly related to OC than extrinsic rewards are.

\section{The level of education and comparative importance of rewards}

University graduates are considered to be more modernized or westernized and have more individualized views than other employees. Thus, the OC of university graduates is expected to be more related to extrinsic and intrinsic rewards and less related to social rewards than the OC of others (Boyacigiller \& Adler, 1991). This leads us to the following hypotheses:

Hypothesis 9: The relationship between benefit satisfaction and $\mathrm{OC}$ is stronger for university graduates than for others.

Hypothesis 10: The relationship between fatigue and $O C$ is stronger for university graduates than for others.

Hypothesis 11: The relationship between supervisor support and $O C$ is weaker for university graduates than for others.

Hypothesis 12: The relationship between coworker support and $\mathrm{OC}$ is weaker for university graduates than for others.

Hypothesis 13: The relationship between autonomy and $O C$ is stronger for university graduates than for others.

Hypothesis 14: The relationship between training provision and $\mathrm{OC}$ is stronger for university graduates than for others.

Hypothesis 15: The relationship between role clarity and $O C$ is stronger for university graduates than for others.

Finally, from Hypotheses 9 to 15, we are led to the following hypotheses:

Hypothesis 16: The relationship between extrinsic rewards (benefit satisfaction; fatigue) and $\mathrm{OC}$ is stronger for university graduates than for others.

Hypothesis 17: The relationship between social rewards (supervisor support; coworker support) and $\mathrm{OC}$ is weaker for university graduates than for others.

Hypothesis 18: The relationship between intrinsic rewards (autonomy; training provision; role clarity) and $\mathrm{OC}$ is stronger for university graduates than for others.

\section{Research Methodology}

Participants

We sent questionnaires to employees in 64 Japanese manufacturing companies

in China, from April 2007 to March 2016. 50,000 questionnaires were distributed via the HR 
departments of the participant companies. Nearly all the employees were asked to take part in the survey to avoid any sampling bias, which may have an uncontrollable impact on the survey results. After being promised a copy of the summary results, the HR department of each firm distributed the questionnaires and collected the completed questionnaires. Each respondent was asked to put the completed questionnaire into the provided envelope and seal it himself/herself, to guarantee complete anonymity. Overall, 45,874 surveys were collected, reflecting a response rate of $91.7 \%$. However, we eliminated 18,020 surveys due to missing values or inappropriate participants for this research (e.g., contract employees, foreign workers, Japanese expatriates, etc.). Consequently, the final sample comprised 27,854 Chinese participants: 5,166 university graduates and 22,688 non-graduates.

As the sample size is larger and covers a wider area than past research, the estimated figures may be regarded as more representative of Chinese employees who work for Japanese companies in China. Likewise, since the survey period is quite long and there is almost 9 years' difference between the first and last participants, the data establishes more representative trends by mitigating the effects of any single incident. China has experienced various social and economic changes in this period, so employee data may be misleading if it is limited to a particular period. Demographic information for the participants is shown in the tables in the appendix. We controlled for all the demographic variables in order to attenuate any concerns about sample compatibility.

\section{Measures}

Most questions used in this research were developed by IEWRI (1996) and later adopted by Kokubun (2006). IEWRI, the International Economy and Work Research Institute, is a research institute located in Osaka that conducts employee opinion surveys for members of trade unions at more than 300 representative Japanese companies, and gives them practical advice on activating their organizations and enhancing corporate productivity. They base this advice on the survey results, as well as on theories of social psychology and support from university professors and researchers (http://www.iewri.or.jp/). The main reason for using IEWRI's questions in this study is because this research is also designed to provide practical advice on how to enhance the commitment or motivation of local employees in Japanese companies located in foreign countries. A secondary reason is that IEWRI has a rich opinion database of Japanese employees who work for Japanese companies obtained by similar methods, which we plan to use for international comparisons in future research. The original questionnaire was developed in English and then translated into Chinese. To ensure the accuracy of the translation, the questionnaire was then translated back into English.

Benefit satisfaction. Benefit satisfaction was measured on a four-item scale developed by IEWRI (1996). The items were measured on a five-point scale that ranged from 1 (dissatisfied) to 5 (satisfied). The alpha reliability was 0.799 for university graduates and 0.760 for others.

Fatigue. Fatigue was measured on a five-item scale developed by IEWRI (1996). The items were measured on a five-point scale that ranged from 1 (incorrect) to 5 (correct). The alpha reliability was 0.858 for university graduates and 0.837 for others.

Supervisor support. Supervisor support was measured on a six-item scale originally developed by Kokubun (2006), using Eisenberger et al. (1986) as a reference, except for one item developed by IEWRI (1996): "My boss/supervisor gives me sufficient information about the management policy of the company and the division." The items were measured on a five-point scale that ranged from 1 (I don't think so) to 5 (I think so). The alpha reliability was 0.902 for university graduates and 0.881 for others.

Co-worker support. Co-worker support was measured on a four-item scale originally developed by Kokubun (2006), using Eisenberger et al. (1986) as a reference. The items were measured on a five-point scale that ranged from 1 (I don't think so) to 5 (I think so). The alpha reliability was 0.796 for university graduates and 0.774 for others.

Autonomy. Autonomy was measured on a four-item scale developed by IEWRI (1996). The 
items were measured on a five-point scale that ranged from 1 (I don't feel so) to 5 (I feel so). The alpha reliability was 0.739 for university graduates and 0.715 for others.

Training provision. Training provision was measured on a three-item scale developed by IEWRI (1996). The items were measured on a five-point scale that ranged from 1 (I don't think so) to 5 (I think so). The alpha reliability was 0.763 for university graduates and 0.736 for others.

Role clarity. Role clarity was measured on a two-item scale developed by IEWRI (1996). The items were measured on a five-point scale that ranged from 1 (I don't think so) to 5 (I think so). The alpha reliability was 0.760 for university graduates and 0.539 for others.

Organizational commitment. Five items were used to measure OC. Three items were adopted from IEWRI (1996), and the researcher added two items: "I have a strong will to work hard in this company" and "I am willing to contribute to the development of this company." The items were measured on a five-point scale that ranged from 1 (I don't think so) to 5 (I think so). The alpha reliability was 0.839 for university graduates and 0.832 for others.

Control variables. Several demographic variables were included to control for individual differences. Answer data without any conversion was used for age and organizational tenure. The sample dummy shows university graduates or others. Gender, turnover experience, marital status, indirect/direct department, managerial/non-managerial position, Northeast/North/East/South region, and the year of participation in the survey were also measured.

\section{Analysis and findings}

We conducted an exploratory factor analysis of all the items (except the control variables) to examine measurement invariance between university graduates and others. The results of the factor analysis with varimax rotation are presented in Table 1, confirming an eight-factor solution for the following items: benefit satisfaction, fatigue, supervisor support, co-worker support, autonomy, training provision, role clarity, and OC. The factor structure was the same for university graduates and others; therefore, we are convinced that both university graduates and others ascribed the same meanings to the scale items used in the current study (Milfont \& Fischer, 2010). For the same reasons, we decided not to use six low-factor-loading items, including three items under benefit satisfaction (i.e., "Company's evaluation of myself," "Facilities and equipment of the company," and "Holidays and working hours"), two items under co-worker support (i.e., "I have good cooperation from my co-workers in my workplace" and "My co-workers are willing to teach me what I do not know about my work") and one item under organizational commitment (i.e., "I am attracted to the slogan of the company and the strategies to achieve it"). According to the result of exploratory factor analysis to prevent multicollinearity with other variables, the parties did not ascribe the same meanings to these items.

Descriptive statistics for both university graduates and others are presented in Table 2. We tested our hypotheses using hierarchical regression analysis. We entered the control variables in Step 1 and the main effects of benefit satisfaction, fatigue, supervisor support, co-worker support, autonomy, training, and role clarity in Step 5. In Step 6, we entered the sample variable ( 1 for university graduates and 0 for others) and its interaction terms with main effects for the entire sample, to test university graduate moderation. Variables forming the interaction term were entered to minimize multicollinearity among the interaction terms and their components (Aiken \& West, 1991). In Steps 2 to 4, the main effects were separately entered by the kind of rewards (extrinsic, social, and intrinsic rewards) to test their comparative importance. In addition, we conducted a separate regression analysis using university graduates and others. All regression results are presented in Table 3.

Step 1 presents the results when only the control variables are included in the regression, to predict OC. Ten out of eleven demographic variables were found to influence OC. Among them, age, turnover experience, marital status, indirect department, position, 
northeast, north, east, and year were positively related to $\mathrm{OC}$, while gender was negatively related to OC. That means that employees who were female, aged, married, had indirect and managerial positions with experience working for other companies, and those working in a region other than South tend to have higher OC than their counterparts. The analysis also indicated that $\mathrm{OC}$ is becoming higher as time goes by.

Step 2 presents the results when two variables of extrinsic rewards are added to the regression. Likewise, Steps 3 and 4 present the results when two variables of social rewards and three variables of intrinsic rewards were respectively added to the regression. All seven reward variables were significantly associated with OC. Based on the Adjusted $R^{2}$, extrinsic, social, and intrinsic rewards explained $22 \%, 26 \%$, and $27 \%$ of the additional variance in OC, respectively. This implies that social and intrinsic rewards are important for $\mathrm{OC}$ to the same extent and are more important than extrinsic rewards, supporting Hypothesis 9 . Step 5 presents the results when all seven reward variables are added to the regression. Fatigue is negatively associated to the regression and the other six reward variables are positively associated, all significantly $(p<0.01)$. This model provides support for Hypotheses 1-7.

At Step 6, the relationship between benefit satisfaction and OC was moderated by the sample, showing that their relationship was stronger for university graduates than for others $(\beta=0.05, p<0.01)$. In other words, university graduates' OC was affected more by benefit satisfaction compared with others. Moreover, the relationships of autonomy and role clarity with OC were stronger for university graduates than for others $(\beta=0.08, p<0.01$; $\beta=0.05, p<0.05$ ), which suggests that both factors are more important in forming OC for university graduates than others. However, the relationship of supervisor support with OC was weaker for university graduates than for others $(\beta=-0.05, p<0.05)$, which suggests that support from supervisors is less important in forming $O C$ for university graduates than for others. The significant results of these moderation tests are consistent with Hypotheses $1,3,5$, and 7. Broadly, extrinsic and intrinsic rewards are more important and social rewards are less important predictors of OC for university graduates than for others, supporting Hypotheses 17 to 19 . Additionally, the OC of university graduates is lower than others' OC when it is controlled by other variables $(\beta=-0.18, p<0.01)$.

\section{Results and Discussion}

The objective of the present study was to investigate the antecedents of the organizational commitment (OC) among employees working in Japanese manufacturing companies in China. Our findings demonstrate that extrinsic rewards, social rewards, and intrinsic rewards engendered higher levels of organizational commitment. This supports the findings of previous work conducted on samples from Western organizations, which highlight intrinsic factors as the main influence on OC (Goulet \& Frank, 2002; Steijn \& Leisink, 2006). Likewise, it also matches the findings from previous research in China, which highlights extrinsic and social factors as the main influences (Chiu et al., 2002; Miao et al., 2013; Newman \& Sheikh, 2012). The reason why Japanese companies in China show more similar results to the West than to other kind of corporations in China, in terms of the comparative importance of intrinsic rewards, may be that their headquarters in Japan, a highly developed country, give them easier access to more modernized HRM than other local companies in China.

However, at the same time, we easily notice from more precise observations that Japanese companies in China still function as corporations in a developing and collectivistic country. In line with Hypotheses 1 and 2, benefit satisfaction and fatigue were found to influence organizational commitment with a high degree of significance. This contradicts findings from some of the previous studies in the West, which suggest that extrinsic benefits have limited impact on the commitment of employees (Goulet \& Frank, 2002; Steijn \& Leisink, 2006), but is supportive of findings from work on Chinese organizations (Chiu et al., 2002; Miao et al., 2013; Nazir et al., 2016; Newman \& Sheikh, 2012). These findings might be attributed to the fact that our work was done in the context 
of a transition economy, in which there is a lower standard of living than in the West and individuals are therefore more responsive to financial rewards. In addition, relatively substantial fringe benefits packages provided to employees working for Japanese companies are a major incentive, in light of the recent increases in the cost of living.

In line with Hypotheses 3 and 4, supervisor and co-worker support were also found to have a significant influence on OC. These findings provide further evidence of the importance of social rewards in a collectivistic society such as China. This result may be at the same time a positive observation for Japanese companies which intend to transplant activities to China, as they are also known as collectivistic: members are expected to build strong relationships with their supervisors and co-workers, in a workplace characterized by respect for seniority and high levels of reciprocity between individuals.

Autonomy was found to influence OC, providing support for Hypotheses 5. This is in line with findings from previous empirical work on organizations in the West (Steijn \& Leisink, 2006) and China (Chen \& Aryee, 2007; Miao et al., 2013; Nazir et al., 2016), and suggests that Chinese employees in Japanese companies tend to be more committed if they are provided with discretionary autonomy in their work. Being provided with autonomy should signal to employees that they are trusted and valued by their organization, and in turn engender higher levels of OC. Likewise, a significant relationship between role clarity and organizational commitment, in line with Hypothesis 7, may result from the fact that employees in China tend to become more committed to an organization if they are provided with a clear work division. This result is also in line with most other studies in the West and Asia.

The finding that the provision of training enhances OC, providing support for Hypothesis 6, is in line with most other findings from empirical studies in China and other developing countries, except some research into the public sector in China (Miao et al., 2013). However, it contradicts the findings of some previous work conducted on samples in the West, which finds that training does little to enhance OC. This difference may be attributed to the generally low income level in China, where people cannot fully invest in skill improvement unless they are members of stable and big companies which invest for them. In such a circumstance, a company's training provision will be more easily perceived as a reward and in turn cause an increase of OC.

The significant interaction results as per Hypotheses 9, 13, and 15 suggest that the relationships of $\mathrm{OC}$ with benefit satisfaction, autonomy, and role clarity are greater among university graduates compared with other employees. On the contrary, another significant result supporting Hypothesis 11 implies that the relationship of OC with supervisor support is weaker among university graduates compared with others. These results are also supportive of Hypotheses 16,17, and 18 that the OC of university graduates is more related to extrinsic and intrinsic rewards and less related to social rewards compared to others. On the other hand, insignificant interaction results which contradict Hypotheses 10, 12, and 14 suggest that there is no significant difference between university graduates and others on the relationships of $\mathrm{OC}$ with fatigue, coworker support, and training provision.

\section{Implications for theory and practice}

The present study contributes to the literature in five main ways. First, in line with previous work, it shows that national culture is an important influence on the work attitudes of employees, including organizational commitment (Glazer et al., 2004). Specifically, it highlights differences between the factors that drive the $\mathrm{OC}$ of employees working for Japanese companies in China and employees working in the West. Compared to employees from less hierarchical, more individualistic cultures in the West, employees working for Japanese companies, which represent more collectivistic cultures, typically respond more positively to the existence of social rewards, namely high-quality relationships with others in the workplace. So, it may be reasonable to assume that Japanese companies in China more resemble other companies in China than those in the 
West, insofar as a correlation between $\mathrm{OC}$ and interpersonal relations.

Second, however, it also became apparent that the relationship between rewards and $\mathrm{OC}$ differs by type of company, even though they are located in the same country. The OC of Japanese companies is more associated with intrinsic and social rewards than extrinsic rewards, whereas that of other kinds of corporations is more correlated with extrinsic and social rewards than intrinsic rewards. This finding provides a hypothesis to be tested in future researches: a company which originates from a developed country and is more linked to modernized HRM responds more positively to intrinsic rewards than a local company.

For instance, the concept of kaizen, a kind of corporate culture that supports continual organizational learning and is typically observed in Japanese companies, is said to be based on workers' self-initiative to learn and improve their work processes at all levels of the organization (Koike, 1994; Liker, 2004; Teece et al., 1997). It is difficult to transfer this concept to overseas plants in China by just imposing Japanese methods on Chinese employees unilaterally (Aoki, 2008). So, companies from developed countries, including Japanese companies, may have a somewhat more autonomous culture than those of less developed countries, and have some effects that socialize hired local employees to become more responsive to autonomous ways of working as time goes by. In any case, for managers of Japanese companies who are inclined to rely on monetary rewards and social activities for motivating employees, but do not fully consider the employees' way of working and development opportunities, this result will be very important for improving their management strategies in China and other developing countries.

Third, whereas provision of training has been shown to be less important in several cases in the West, the results of this study demonstrate that for Japanese companies in China it is relatively important, as was similarly shown in other kinds of corporations in China or in other developing countries (Owoyemi et al., 2011; Newman et al., 2011). The reason why the results obtained in China are different from those in the West might be because employees in China generally have immature technical skills and do not face a mismatch between the training their companies provide and the skills the employees want to obtain. As most employees in China do not possess enough resources to enhance their own skills independently, certain training offered by a company may be perceived as enough rewards for them to reciprocate with $\mathrm{OC}$ to the company. The fact that most results obtained in other studies conducted in transitional economies find positive and significant relations between training and OC supports this assertion. Although many companies have tended to reduce expenditures for training due to high turnover rates and the recent economic downturn in China, it will be important to maintain the volume or quality of training to maintain the $\mathrm{OC}$ of employees.

Fourth, this study also clarifies differences between Japanese companies and the public sector in China: whereas provision of training was shown to be less important in the public sector in a previous study (Miao et al., 2013), the results of this study demonstrate that in Japanese companies it is important as in most other enterprises in China (Nazir et al., 2016; Newman et al., 2011) and in some Western organizations (Goulet and Frank, 2002; Steijn and Leisink, 2006). At the same time, this research suggests an important difference between Japanese companies and the private sector in China: although previous studies showed co-worker support to be less important in the private sector in China (He et al., 2011; Newman \& Sheikh, 2012; Wang, 2008), the results of this study show that in Japanese companies it is as important as in the public sector in China. These results indicate that Japanese companies in China have characteristics of both the private and public sectors in China. They have typically introduced and developed more sophisticated HRM than companies in developing countries, leaving their collectivistic cultures without significant changes until the recent economic slowdown. This result is also in line with the opinion of Takeuchi $(1998$, p.3), who described Japan as "a socialist country that pretends to be capitalist."

Lastly, some differences between university graduates and others became clear. 
Benefit satisfaction, autonomy, and role clarity are more important for the former while supervisor support is more important for the latter. Furthermore, the OC of university graduates is lower than others' OC. However, as Japanese expatriate managers dominate information, decision-making, status, and financial resources, many Japanese companies have continued to rely heavily on expatriate managers. The reason for such circumstances is often said to be that Japanese managers have a negative image of the skills or abilities of local employees, which at the same time prohibits them from recruiting highly qualified local employees (NKDR, 2006). In this sense, one of the most significant problems for Japanese companies might be the inability of Japanese managers to completely trust their local employees (Colignon et al., 2007). In contrast to Western companies, jobs in Japanese companies can also be described as flexible at best and ambiguous at worst, and the scope of work can often vary with the employee's personal abilities (Yu \& MeyerOhle, 2008). So, it is often assumed that Japanese companies have failed to attract the most talented employees who want to be employed by a company which provides more authority and specific work division. While this system is increasingly challenged, Japanese companies, despite introducing many elements of their management style, seemingly have not managed, or even attempted, to improve their operations in China.

These results coincide with the fact that many Japanese companies have difficulties attracting university graduates, who prefer to be employed by companies which offer them good treatment, high discretion, and the chance to utilize the specialties they developed at school or less. University graduates also tend to be less interested to having personal relationships with their supervisors. In this sense, Japanese companies may have to reconsider their HRM practices, especially in terms of the payment scheme, job autonomy, and job clarity at the workplace, in order to attract the best university graduates in China. Overall, since Japanese companies in China have characteristics of both Western and Chinese origins along with balanced HRM, focusing not only on some particular rewards but also on more varieties of rewards seems to be effective for enhancing their employees' OC, especially employees with weaker educational backgrounds. However, this balanced HRM may not be equally effective for enhancing the $\mathrm{OC}$ of university graduates who prefer extrinsic and intrinsic rewards to social rewards.

Additionally, let us review the results of the three rewards which showed unexpected results, i.e., no significant difference between university graduates and others in terms of OC. First, we initially expected fatigue to be more strongly negative in association with OC among university graduates, since they are considered to be more individualistic and acquisitive regarding work-life balance. Actually, recent empirical crosscountry research shows that employees from individualistic countries reported a higher perceived workload and higher turnover intentions than their counterparts in collectivistic countries, while working the same number of hours (Yang et al., 2012). However, the relationship between fatigue and $\mathrm{OC}$ might be stronger in non-graduates: since they were less accustomed to work practices in modern industries due to their comparative lack of education, they might be more sensitive to the stress of adapting to regularity and discipline (Kerr et al., 1960). If these possible effects cancel each other out, it may be that fatigue did not have a meaningful way to differentiate them insofar as its relationship with OC.

Regarding another contradictory result, i.e. that co-worker support showed no significant difference in terms of OC between university graduates and others even though the former is considered to be more correlated with OC than the latter, we may attribute it to the culture of this country. Namely, people who strongly value seniority in their human relations, due to the influence of traditional Confucian culture, may rely more on employer relations, especially when they have not experienced higher education. This is because supervisor relations are not merely related to collectivism but also to the ethical view which has generally taken root in Chinese society. On the other hand, relations with co-workers are considered to be less related to Confucian traditions and may not reduce the importance of co-worker support even given higher education.

On the other hand, the finding of no significant difference between graduates and 
non-graduates in the association of training and OC may have to do with financial constraints and training mismatches. Although university graduates may require a larger quantity and higher quality of training than other employees, such requirements may not be fulfilled easily if the company cannot afford to provide such opportunities. This kind of mismatch may be larger for university graduates than for others, as graduates have already cultivated specialties at school so they experience a larger skills gap than other employees. However, this result may also be partly due to the inadequate education systems of Japanese companies, which exclude HCNs from senior promotion opportunities and from managerial training programs (Froese \& Kishi, 2013).

The findings of this study have important implications for senior management in Japanese and other companies in China. In addition to improving the extrinsic benefits of employees, managers should focus on improving social and intrinsic rewards to foster greater OC. Although Japanese companies have focused more on social rewards to foster greater $\mathrm{OC}$, by creating opportunities for employees to interact with each other inside and outside of the workplace, managers might also be encouraged to pay attention to intrinsic rewards, taking more of a participative approach and seeking input from their subordinates in the decision-making process. They can also improve extrinsic rewards, enriching payment and subsidiary schemes to be more attractive. Furthermore, to attract more longterm talented and skilled employees, who are typically university graduates, managers should emphasize intrinsic and extrinsic rewards over social rewards.

\section{Study limitations and suggestions for future research}

The main limitation of this research involves reliability. This study used self-report data from individual respondents, which may have resulted in common method bias. Future research might consider the inclusion of supervisor-rated scales to reduce this bias and strengthen the study design.

\section{Conclusion}

The purpose of this study was to investigate the relationship among extrinsic rewards, intrinsic rewards, social rewards, and the organizational commitment (OC) of 27,854 employees who work for 64 Japanese manufacturing companies in China. Hierarchical regression analysis revealed that variables included to measure extrinsic, social, and intrinsic rewards were strongly related to OC. These findings suggest that the antecedents of organizational commitment in Japanese companies are different from those in other kinds of corporations in China, where extrinsic and social rewards are more correlated with OC than intrinsic rewards. They also differ from companies in the West, where intrinsic rewards are more correlated with OC than extrinsic and social rewards. Overall, balanced HRM will work best given Japanese companies' combination of Western and Chinese characteristics. Managers should not simply focus on one particular type of reward but offer a variety of rewards to enhance employees' OC, especially for employees with less formal education.

The comparison between university graduates and non-graduates showed that extrinsic and intrinsic rewards had a stronger influence on $O C$ for graduates, while social rewards had a weaker influence, suggesting that university graduates are more individualistic than other employees. As Japanese companies are sometimes said to be less attractive as workplaces, especially for university graduates, the results of this research could be utilized to reconsider future human resource management of these companies, to help them attract and employ the best employees who can contribute to the companies on a long-term basis.

\section{References}

Adler, N.J. (1986), International Dimensions of Organizational Behavior, Kent Publishing, Boston, MA.

Aiken, L.S. and West, S.G. (1991), Multiple Regression: Testing and Interpreting 
Interactions, Thousand Oaks, CA: Sage.

Allen, N.J., and Meyer, J.P. (1990), "The measurement and antecedents of affective, continuous, and normative commitment to the organization", Journal of Occupational Psychology, Vo. 63 No. 1, pp. 1-18.

Ando, N. (2014), "The effect of localization on subsidiary performance in Japanese multinational corporations", International Journal of Human Resource Management, Vol. 25 No. 14, pp.1995-2012.

Angle, H.L. and Perry, J.L. (1983), "Organizational commitment: individual and organizational influences", Work and Occupations, Vol. 10, pp. 123-146.

Aoki, K. (2008), "Transferring Japanese kaizen activities to overseas plants in China", International Journal of Operations \& Production Management, Vol. 28 No. 6, pp. 518539.

Bartlett, K.R. (2001), "The relationship between training and organizational commitment: a study in the health care field", Human Resource Development Quarterly, Vol. 12 No. 4, pp. 335-352.

Barrett, A. and O'Connell, P.J. (2001), "Does training generally work? The returns to incompany training", Industrial and Labor Relations Review, Vol. 54 No. 3, pp. 647-662.

Becker, G.S. (1993), Human capital: A theoretical and empirical analysis with special reference to education (3rd ed.), Chicago, IL: University of Chicago Press.

Beukhof, G., De Jong, M.J. and Nijhof, W.J. (1998), "Employee commitment in changing organization: an exploration", Journal of European Industrial Training, Vol. 22 No. 6, pp. 243-248.

Black, J.S. and Morrison, A.J. (2010), Sunset in the Land of the Rising Sun: Why Japanese Multinational Corporations Will Struggle in the Global Future. Basingstoke, UK: Palgrave Macmillan.

Boyacigiller, N. and Adler, N.J. (1991), "The parochial dinosaur: organizational suicide in global context", Academy of Management Review, Vol. 16, pp. 262-290.

Burke, R.J. (1995), "Benefits of formal training courses within a professional services firm", The Journal of Management Development, Vol. 14 No. 3, pp. 3-13.

Caught, K., Shadur, M.A., \& Rodwell, J.J. (2000), "The measurement artifact in the Organizational Commitment Questionnaire", Psychological Reports, Vol. 87 No. 3, pp. 777-788.

Chan, A.W. Feng, T.Q., Redman, T., and Snape, E. (2006), "Evaluating the multidimensional view of employee commitment: a comparative UK-Chinese study", International Journal of Human Resource Management, Vol. 17 No. 11, pp. 1873-1887.

Chen, Z.X. and Aryee, S. (2007), "Delegation and employee work outcomes: An examination of the cultural context of mediating processes in China", Academy of Management Journal, Vol. 50, pp. 226-238.

Chen, Z.X. and Francesco, A.M. (2000), "Employee demography, organizational commitment, and turnover intentions in China: do cultural differences matter?' Human Relations, Vol. 53 No. 6, pp. 869-887.

Chen, Z.X., Tsui, A.S. and Farth, J.L. (2002), "Loyalty to supervisor vs. organizational commitment: relationships to employee performance in China", Journal of Occupational and Organizational Psychology, Vol. 75 No. 3, pp. 339-356.

Cheng, B.S., Jiang, D.Y. and Riley, J.H. (2003), "Organizational commitment, supervisory commitment, and employee outcomes in the Chinese context: proximal hypothesis or global hypothesis?", Journal of Organizational Behavior, Vol. 24 No. 3, pp. 313-334.

Chiaburu, D.S. and Harrison, D.A. (2008), "Do pees make the place? Conceptual synthesis and meta-analysis of co-worker effects on perceptions, attitudes, OCBs, and performance", Journal of Applied Psychology, Vol. 93 No. 5, pp. 1082-1103.

Chiu, R.K., Luk, V.W.M. and Tang, T.L.P. (2002), "Retaining and motivating employees: Comparison preferences in Hong Kong and China", Personnel Review, Vol. 31 No. 4, pp. 402-431.

CJCCI (The Japanese Chamber of Commerce and Industry in China) (2016), Chugoku 
Kigyo to Nihon Kigyo 2016 nen Hakusyo (Chinese Economy and Japanese Companies 2016 White Paper). (Japanese)

Colignon, R.A., Usui, C. and Kerbo, H.R. (2007), "Employee commitment in U.S. and Japanese firms in Thailand", Asian Social Science, Vol. 3 No. 11, pp. 16-30.

Eby, L.T., Freeman, D.M., Rush, M.C. and Lance, C.E. (1999), "Motivational bases of affective organizational commitment: a partial test of an integrative theoretical model", Journal of Occupational and Organizational Psychology, Vol. 72 No. 4, pp. 463-483.

Eisenberger, R., Huntington, R., Hutchison, S. and Sowa, D. (1986), "Perceived organizational support", Journal of Applied Psychology, Vol. 71, pp. 500-507.

Froese, F.J. and Kishi, Y. (2013), "Organizational attractiveness of foreign firms in Asia: soft power matters", Asian Business \& Management, Vol. 12 No. 3, pp.281-297.

Froese, F.J. and Xiao, S. (2012), "Work values, job satisfaction and organizational commitment in China", International Journal of Human Resource Management, Vol. 23 No. 10 , pp. 2144-2162.

Furusawa, M., Brewster, C. and Takashina, T. (2016), "Normative and systems integration in human resource management in Japanese multinational companies", Multinational Business Review, Vol. 24 No. 2, pp. 82-105.

Gamble, J. and Tian, A.W. (2015), "Intra-national variation in organizational commitment: evidence from the Chinese context", International Journal of Human Resource Management, Vol. 26 No. 7, pp. 948-970.

Gergersen, H.B. and Black, J.S. (1996), "Multiple commitment upon repatriation: the Japanese experience", Journal of Management, Vol. 22 No. 2, pp. 209-229.

Glazer, S., Daniel, S.C. and Short, K.M. (2004), "A study of the relationship between organizational commitment and human values in four countries", Human Relations, Vol. 57 No. 3, pp. 323-345.

Goulet, L.R. and Frank, M.L. (2002), "Organizational commitment across three sectors: Public, non-profit, and for-profit", Public Personnel Management, Vol. 31 No. 2, pp. 201210.

Haar, J.M. and Spell, C.S. (2004), "Programme knowledge and value of work-family practices and organizational commitment", International Journal of Human Resource Management, Vol. 15 No. 6, pp. 1040-1054.

Haghirian, P. (2010), Innovation and Change in Japanese Management, Springer.

He, Y., Lai, K.K. and Lu, Y. (2011), "Linking organizational support to employee commitment: Evidence from hotel industry of China", International Journal of Human Resource Management, Vol. 22 No. 1, pp. 197-217.

Hofstede, G. (1980), Culture's Consequence, Beverly Hills, CA: Sage Publications.

IEWRI (International Economy and Work Research Institute) (1996), ONION2 Sankagata Soshiki toshiteno Rodo Kumiai no Saisei: Syakai Sinrigaku karano Teigen (ONION2: Renovation of Trade Union as an Organization for Participation and Engagement), International Economy and Work Research Institute. (Japanese)

Jackson, K. and Tomioka, M. (2004), The Changing Face of Japanese Management, London: Routledge.

JETRO (Japan External Trade Organization) (2016a), 2015 nen no Taichu Chokusetsu Toshi Doko (Direct Investment Trend in China 2015), July 2016. (Japanese)

JETRO (Japan External Trade Organization) (2016b), Statistics of Direct Investment, Japan External Trade Organization. (Japanese)

JRI (The Japan Research Institute) (2008), Chugoku Rodoshijo niokeru Rodoryokuido to Jukyu Mismatch no Genjo to Tenbo (Current Conditions and Prospects of Labor Force Movement and Supply-Demand Mismatch in Labor Market in China). (Japanese)

Kerr, C., Dunlop, J.T., Harbison, F.H. \& Myers, C.A. (1960), Industrialism and Industrial Man: The Problems of Labour and Management in Economic Growth, Cambridge Mass.: Harvard University Press.

Koike, K. (1994), "Learning and incentive systems in Japanese industry", in Aoki, M. and Dore, R. (Eds), The Japanese Firms: Sources of Competitive Strength, Oxford 
University Press, New York, NY, pp. 41-65.

Kokubun, K. (2006), Globalization and Industrial Reallocation: How to Motivate Malaysian Workers, A paper presented at the 3rd International Globalization Studies Network (GSN) Conference, Universiti Kebangsaan Malaysia.

Komai, H. (1989), Japanese Management Overseas: Experiences in the United States and Thailand, Tokyo: Asian Productivity Organization.

Konomoto, S. (2000), "Problems of Japanese companies in east and southeast Asia", Nomura Working Paper, Vol. 18, Nomura Research Institute, Tokyo.

Korczynski, M., Shire, K., Frenkel, S. and Tam, M. (2000), "Service work in customer capitalism: Customers, control and contradictions", Work, Employment and Society, Vol. 14 No. 4 , pp. 669-688.

Lee, R.T. and Ashforth, B.E. (1996), "A meta-analytic examination of the correlates of the three dimensions of job burnout", Journal of Applied Psychology, Vol. 81 No. 2, 123133.

Legewie, J. (2002), "Control and co-ordination of Japanese subsidiaries in China: Problems of an expatriate-based management system", International Journal of Human Resource Management, Vol. 13 No. 6, pp. 901-919.

Liker, J.K. (2004), The Toyota Way: 14 Management Principles from the World's Greatest Manufacturer, McGraw-Hill, New York, NY.

Loscocco, K.A. (1990), "Reactions to blue-collar work: a comparison of women and men", Work and Occupations, Vol. 17 No. 2, pp. 152-177.

Malhotra, N., Budhwar, P. and Prowse, P. (2007), "Linking rewards to commitment: an empirical investigation of four UK call centres", International Journal of Human Resource Management, Vol. 18 No. 12, pp. 2095-2128.

Mathieu, J.E. and Zajec, D.M. (1990), "A review and meta-analysis of the antecedents, correlates and consequences of organizational commitment", Psychological Bulletin, Vol. 108 No. 2, pp. 171-194.

Meyer, J.P. and Allen, N.J. (1991), "A three-component conceptualization of organizational commitment", Human Resource Management Review, Vol. 1, pp. 61-98.

Meyer, J.P. and Smith, C.A. (2000), "HRM practices and organizational commitment: Test of a mediation model", Canadian Journal of Administrative Sciences, Vol. 17 No. 4, pp. 319-331.

Meyer, J.P., Stanley, D.J., Herscovitch, L. and Topolnysky, L. (2002), "Affective, continuous, and normative commitment to the organization: a meta-analysis of antecedents, correlates, and consequences", Journal of Vocational Behavior, Vol. 61, pp. 20-52.

Miao, Q., Newman, A., Sun, Y. and Xu, L. (2013), "What factors influence the organizational commitment of public sector employees in China? The role of extrinsic, intrinsic and social rewards", International Journal of Human Resource Management, Vol. 24 No. 17, pp. 3262-3280.

Milfont, T.L. and Fischer, R. (2010), 'Testing measurement invariance across groups: applications in cross-cultural research", International Journal of Psychological Research, Vol. 3, pp. 111-121.

METI (Ministry of Economy, Trade and Industry of Japan) (2016), Dai 46 kai Kaigaijigyokatsudo Kihonchosagaiyo (Summary Report: 46th Basic Survey of Foreign Business Activities). (Japanese)

Mottaz, C.J. (1985), 'The Relative Importance of Intrinsic and Extrinsic Rewards as Determinants of Work Satisfaction", Sociological Quarterly, Vol. 26 No. 3, pp. 365-385.

Mottaz, C.J. (1988), "Determinants of Organizational Commitment", Human Relations, Vol. 41 No. 6 , pp. 467-482.

Mowday, R.T., Porter, L.W. and Steers, R.M. (1982), Employee-Organization Linkages: The Psychology of Commitment, Absenteeism and Turnover, New York, NY: Academic Press.

Nazir, S., Shafi, A., Qun, W., Nazir, N. and Tran, Q. D. (2016), "Influence of organizational rewards on organizational commitment and turnover intentions", Employee Relations, 
Vol. 38 No. 4, pp. 596-619.

Newman, A. and Sheikh, A.Z. (2012), "Organizational commitment in Chinese small- and medium-sized enterprises: the role of extrinsic, intrinsic and social rewards", International Journal of Human Resource Management, Vol. 23 No. 2, pp. 349-367.

Newman, A., Thanacoody, R. and Hui, W. (2011), "The impact of employee perceptions of training on organizational commitment and turnover intentions: a study of multinationals in the Chinese service sector", International Journal of Human Resource Management, Vol. 22 No. 8, pp. 17651-1787.

Nujjoo, A. and Meyer, I. (2012), 'The relative importance of different types of rewards for employee motivation and commitment in South Africa", SA Journal of Human Resource Management, Vol. 10 No. 2, 10-pages.

NKDR (Nihon Keizai Dantai Rengokai). (2006), Nihon Kigyo no Chugoku ni okeru White Collar Jinzai Senryaku (Employment Strategies for White-collar Employees of Japanese Corporations in China). 16 May 2006.

O'Reilly, C.A. and Caldwell, D.F. (1980), "Job choice: the impact of intrinsic and extrinsic factors on subsequent satisfaction and commitment", Journal of Applied Psychology, Vol. 65 No. 5, pp. 559-565.

Owens, P.L. (2006), "One more reason not to cut your training budget: the relationship between training and organisational outcomes", Public Personnel Management, Vol. 35 No. 2, pp. 163-171.

Owoyemi, O.A., Oyelere, M. and Elegbede, T. (2011), “Enhancing employees' commitment to organisation through training", International Journal of Business and Management, Vol. 6 No. 7, pp. 280-286.

Peyyer, C., Jordan, C., Firms, I. and Travaglione, A. (2010), "Predicting turnover intentions", Management Research Review, Vol. 33 No. 9, pp. 911-923.

Phipps, S.T., Prieto, L.C. and Ndinguri, E.N. (2013), "Understanding the impact of employee involvement on organizational productivity: The moderating role of organizational commitment", Journal of Organizational Culture, Communication and Conflict, Vol. 17 No. 2, pp. 107-120.

Porter, L.W. and Lawler, E.E. (1968), Managerial Attitudes and Performance, Homewood, IL: Dorsey Press.

Pudelko, M. and Tenzer, H. (2013), "Subsidiary control in Japanese, German and U.S. multinational corporations: Direct control from headquarters versus indirect control through expatriation", Asian Business \& Management, Vol. 12 No. 4, pp. 409-431.

Ralston, D.A., Holt, D.H., Terpstra, R.H. and Kai-Cheng, Y. (2008), "The impact of national culture and economic ideology on managerial work values: A study of the United States, Russia, Japan, and China", Journal of International Business Studies, Vol. 39 No. 1, pp. 8-26.

RMS (Recruit Management Solutions). (2012), Chugoku niokeru Nikkeikigyo no Image to Daigakusei ga Kigyo ni Motomerukoto (Image Towards Japanese Companies in China and What University Students Ask Companies for). (Japanese)

Rizzo, J.R., House, R.J. and Lirtzman, S.I. (1970), "Role conflict and ambiguity in complex organizations", Administrative Science Quarterly, Vol. 15 No. 2, pp. 150-163.

Sekiguchi, T., Froese, F. J. and Iguchi, C. (2016), "International human resource management of Japanese multinational corporations: challenges and future directions", Asian Business \& Management, Vol. 15 No. 2, pp. 83-109.

Self, D.R., Holt, D.T. and Schaninger, W.S. (2005), "Work-group and organizational support: a test of distinct dimensions", Journal of Occupational and Organizational Psychology, Vol. 78 No. 1, pp. 133-140.

Shiraki, M. (2012). "Nihonkigyo no globalization to kaigaihakensha: Asia no genchi staff niyoru joshihyoka karano kento (Japanese companies' globalization and overseas expatriates: Examination by local staffs' evaluation towards supervisors in Asia)", Nihon Rodo Kenkyu Zasshi, Vol. 623, pp. 5-16. (Japanese)

Shore, L.M. and Barksdale, K. (1998), "Examining degree of balance and level of obligation 
in the employment relationship: a social exchange approach", Journal of Organizational Behavior, Vol. 19, pp. 731-744.

Sims, H.P., Szilagyi, A.D. and McKemey, D.R. (1976), "Antecedents of work related expectancies", Academy of Management Journal, Vol. 19 No. 4, pp. 547-559.

Smeenk, S.G.A, Eisinga, R.N., Teelken, J.C. and Doorewaard, J.A.C.M. (2006), 'The effect of HRM practices and antecedents on organizational commitment among university employees", International Journal of Human Resource management, Vol. 17 No. 12, pp. 2035-2054.

Steers, R.M. (1977), "Antecedents and outcomes of organizational commitment", Administrative Science Quarterly, Vol. 22 No. 1, pp. 46-56.

Steijn, B. and Leisink, P. (2006), "Organizational commitment among Dutch public sector employees", International Review of Administrative Sciences, Vol. 72 No. 2, pp. 187201.

Takeuchi, Y. (1998), "Japan's transition from socialism to capitalism", The Japanese Political Economy, Vol. 26 No. 2, pp. 3-24.

Teece, D., Pisano, G. and Shuen, A. (1997), "Dynamic capabilities and strategic management", Strategic Management Journal, Vol. 18 No. 7, pp. 509-533.

Triandis, H.C. (1989), 'The self and social behavior in differing cultural context", Psychological Review, Vol. 96, pp. 506-520.

Tungli, Z. and Peiperl, M. (2009), "Expatriate practices in German, Japanese, UK, and US multinational companies: A comparative survey of changes", Human Resource Management, Vol. 48 No. 1, 153-171.

UNCTAD (2004), World Investment Report 2004: The Shift towards Services, New York and Geneva: United Nations.

UNCTAD (2010), World Investment Report 2010, New York and Geneva: United Nations.

Wan, S. (2009), Chugoku Shinsyutsu Nikkeikigyo no Rodo CSR (Labor CSR of Japanese companies in China). (Japanese)

Wang, Y. (2008), "Emotional bonds with supervisors and co-workers: relationship to organizational commitment in China's foreign-invested companies", International Journal of Human Resource Management, Vol. 19 No. 5, pp. 916-931.

Wasti, S.A. (1998), "Cultural barriers in the transferability of Japanese and American human resources practices to developing countries: the Turkish case", International Journal of Human Resource Management, Vol. 9 No. 4, pp. 608-631.

Wayne, S.J., Shore, L.M. and Liden, R. (1997), "Perceived organizational support and leader-member exchange: A social exchange perspective", Academy of Management Journal, Vol. 40 No. 1, pp. 82-111.

Whitney, R. (1994), Business Systems in Asia: Firms, Markets and Societies, London, Newbury Park, Sage publications.

Williamson, I.O., Burnett, M.F. and Bartol, K.M. (2009), "The interactive effect of collectivism and organizational rewards on affective organizational commitment", Cross Cultural Management: An International Journal, Vol. 16 No. 1, pp. 28-43.

Wong, H.W. (2010), "Why a globalizing corporate culture still inhibits localization of management: the Yaohan case", Sangyo Keiei Kenkyu, Vol. 32 No. 1, pp. 31-48.

World Bank (2016), World Development Indicators (WDI), http://data.worldbank.org/data-catalog/world-development-indicators

Wright, T.A. and Cropanzano. R. (1998), "Emotional exhaustion as a predictor of job performance and voluntary turnover", Journal of Applied Psychology, Vol. 83 No. 3, pp. 486-493.

Yoshihara, H. (1989), Genchijin Shacho to Uchinaru Kokusaika: Global Keiei no Kadai (Host-country National CEOs and Internal Internationalization: Issues for Global Management), Tokyo: Tokyo Keizai Shimposha.

Young, B.S., Worchel, S. and Woehr, D.J. (1998), "Organizational commitment among public service employees", Public Personnel Management, Vol. 27 No. 3, pp. 339-348.

Yan, X. (2010), Nihonkigyo niyoru Taichusinsyutu no Chiikibunpu (Japanese Companies' 
Regional Distribution in China).

Yang, L.Q. et al. (2012), "Individualism-collectivism as a moderator of the work demandsstrains relationship: Across-level and cross-national examination", Journal of International Business Studies, Vol. 43 No. 4, pp. 424-443.

Yu, J. and Meyer-Ohle, H. (2008), "Working for Japanese corporations in China: A qualitative study", Asian Business and Management, Vol. 7 No. 1, pp. 33-51.

Zhang, J. (2003), "Nikkei kigyo no jinji romu kanri to chingin mondai: kawaru Chugokujin no ishiki to kawaranu Nihonteki keiei (The labor management of Japanese companies and the problems of its wage system: the changing concepts of Chinese and the changeless Japanese management)", Asia Market Review Vol. 15 No. 10, pp. 34-36. (Japanese) 


\begin{tabular}{|c|c|c|c|c|c|c|c|c|c|c|c|c|c|c|c|c|}
\hline \multirow[b]{2}{*}{ Items } & \multicolumn{8}{|c|}{ University graduates } & \multicolumn{8}{|c|}{ Non-graduates } \\
\hline & $\begin{array}{c}\text { Benefit } \\
\text { satisfaction }\end{array}$ & Fatigue & $\begin{array}{c}\text { Supervisor } \\
\text { support }\end{array}$ & $\begin{array}{c}\text { Co-workers } \\
\text { support }\end{array}$ & Autonomy & $\begin{array}{c}\text { Training } \\
\text { provision }\end{array}$ & Role Clarity & $\begin{array}{l}\text { Organizatio } \\
\text { nal } \\
\text { commitment }\end{array}$ & $\begin{array}{c}\text { Benefit } \\
\text { satisfaction }\end{array}$ & Fatigue & $\begin{array}{c}\text { Supervisor } \\
\text { support }\end{array}$ & $\begin{array}{c}\text { Co-workers } \\
\text { support }\end{array}$ & Autonomy & $\begin{array}{c}\text { Training } \\
\text { provision }\end{array}$ & Role Clarity & $\begin{array}{c}\text { Organizatio } \\
\text { nal } \\
\text { commitment }\end{array}$ \\
\hline Amount of my salary or wage. & 0.73 & -0.11 & 0.14 & 0.04 & 0.06 & 0.13 & 0.06 & 0.21 & 0.72 & -0.17 & 0.17 & 0.04 & 0.09 & 0.08 & 0.06 & 0.13 \\
\hline Possibility of my promotion. & 0.66 & -0.07 & 0.23 & 0.10 & 0.12 & 0.19 & 0.04 & 0.17 & 0.54 & -0.09 & 0.22 & 0.08 & 0.15 & 0.19 & 0.07 & 0.13 \\
\hline My position or rank at the working place. & 0.60 & -0.07 & 0.26 & 0.17 & 0.12 & 0.18 & 0.12 & 0.18 & 0.52 & -0.11 & 0.23 & 0.13 & 0.12 & 0.19 & 0.13 & 0.18 \\
\hline Welfare system of the company. & 0.41 & -0.18 & 0.17 & 0.04 & 0.07 & 0.21 & 0.09 & 0.26 & 0.49 & -0.16 & 0.17 & 0.06 & 0.06 & 0.12 & 0.05 & 0.22 \\
\hline I often feel exhausted. & -0.06 & 0.93 & -0.08 & -0.07 & -0.07 & -0.06 & -0.05 & -0.08 & -0.11 & 0.90 & -0.09 & -0.05 & -0.08 & -0.07 & -0.04 & -0.09 \\
\hline After finishing my work, I feel exhausted. & -0.09 & 0.75 & -0.08 & -0.03 & -0.02 & -0.03 & -0.06 & -0.05 & -0.16 & 0.72 & -0.09 & -0.01 & -0.08 & 0.00 & -0.02 & -0.04 \\
\hline I feel exhausted when I wake up in the morning. & -0.10 & 0.72 & -0.07 & -0.05 & -0.08 & -0.06 & -0.06 & -0.13 & -0.11 & 0.70 & -0.09 & -0.06 & -0.10 & -0.06 & -0.04 & -0.13 \\
\hline My boss/supervisor is trustful. & 0.13 & -0.08 & 0.80 & 0.15 & 0.09 & 0.06 & 0.07 & 0.16 & 0.16 & -0.09 & 0.79 & 0.17 & 0.11 & 0.05 & 0.04 & 0.15 \\
\hline My boss/supervisor treats employees fairly. & 0.24 & -0.07 & 0.77 & 0.17 & 0.10 & 0.10 & 0.09 & 0.12 & 0.25 & -0.11 & 0.74 & 0.13 & 0.12 & 0.09 & 0.07 & 0.13 \\
\hline My boss/supervisor deals with employees' complaints effectively. & 0.21 & -0.08 & 0.73 & 0.13 & 0.12 & 0.17 & 0.10 & 0.15 & 0.21 & -0.09 & 0.71 & 0.10 & 0.13 & 0.13 & 0.08 & 0.15 \\
\hline My boss/supervisor trusts workers. & 0.11 & -0.07 & 0.72 & 0.18 & 0.08 & 0.04 & 0.08 & 0.14 & 0.14 & -0.09 & 0.69 & 0.16 & 0.11 & 0.03 & 0.03 & 0.15 \\
\hline $\begin{array}{l}\text { My boss/supervisor is willing to instruct the employees what they do not } \\
\text { know about their work. }\end{array}$ & 0.04 & -0.04 & 0.67 & 0.17 & 0.10 & 0.21 & 0.10 & 0.16 & 0.03 & -0.03 & 0.61 & 0.12 & 0.04 & 0.23 & 0.14 & 0.17 \\
\hline $\begin{array}{l}\text { My boss/supervisor gives me sufficient information about the } \\
\text { management policy of the company and the division. }\end{array}$ & 0.15 & -0.05 & 0.55 & 0.10 & 0.15 & 0.26 & 0.11 & 0.16 & 0.11 & -0.05 & 0.49 & 0.11 & 0.09 & 0.28 & 0.14 & 0.19 \\
\hline My co-workers are trustful. & 0.15 & -0.06 & 0.23 & 0.75 & 0.10 & 0.09 & 0.09 & 0.17 & 0.13 & -0.05 & 0.20 & 0.77 & 0.10 & 0.08 & 0.09 & 0.13 \\
\hline My co-workers trust me. & 0.04 & -0.03 & 0.20 & 0.69 & 0.20 & 0.07 & 0.05 & 0.18 & 0.05 & -0.02 & 0.14 & 0.73 & 0.16 & 0.07 & 0.07 & 0.18 \\
\hline $\begin{array}{l}\text { My co-workers are willing to teach me what I do not know about my } \\
\text { work. }\end{array}$ & 0.06 & -0.04 & 0.19 & 0.50 & 0.16 & 0.15 & 0.15 & 0.15 & 0.04 & -0.03 & 0.19 & 0.43 & 0.12 & 0.20 & 0.19 & 0.18 \\
\hline I have good cooperation from my co-workers in my workplace. & 0.11 & -0.11 & 0.23 & 0.47 & 0.15 & 0.14 & 0.22 & 0.19 & 0.09 & -0.07 & 0.19 & 0.44 & 0.13 & 0.17 & 0.24 & 0.20 \\
\hline My own ideas are fully utilized in my work. & 0.24 & -0.08 & 0.18 & 0.10 & 0.63 & 0.14 & 0.10 & 0.17 & 0.16 & -0.08 & 0.13 & 0.08 & 0.67 & 0.14 & 0.03 & 0.16 \\
\hline I carry out my work by observing and planning it by myself. & 0.11 & -0.08 & 0.14 & 0.11 & 0.59 & 0.05 & 0.13 & 0.17 & 0.12 & -0.10 & 0.11 & 0.04 & 0.63 & 0.05 & 0.06 & 0.11 \\
\hline I can fully utilize my talentability in my work. & 0.22 & -0.03 & 0.16 & 0.13 & 0.57 & 0.19 & 0.14 & 0.24 & 0.12 & -0.03 & 0.10 & 0.12 & 0.53 & 0.17 & 0.13 & 0.18 \\
\hline I can mostly solve the problems that arise in my work. & -0.10 & -0.02 & 0.02 & 0.18 & 0.46 & 0.02 & 0.05 & 0.15 & -0.02 & -0.05 & 0.05 & 0.12 & 0.44 & 0.02 & 0.05 & 0.13 \\
\hline $\begin{array}{l}\text { For the past one year, I was given useful training to develop ability and } \\
\text { achieve my target. }\end{array}$ & 0.27 & -0.08 & 0.19 & 0.09 & 0.08 & 0.65 & 0.08 & 0.13 & 0.28 & -0.06 & 0.19 & 0.11 & 0.15 & 0.63 & 0.06 & 0.13 \\
\hline In my work, I can master new skills and develop my ability. & 0.21 & -0.07 & 0.18 & 0.16 & 0.20 & 0.57 & 0.04 & 0.21 & 0.16 & -0.06 & 0.17 & 0.15 & 0.25 & 0.55 & 0.04 & 0.21 \\
\hline $\begin{array}{l}\text { At work, the bosses/supervisors and the seniors are training their } \\
\text { subordinates. }\end{array}$ & 0.17 & -0.05 & 0.33 & 0.19 & 0.08 & 0.55 & 0.12 & 0.17 & 0.16 & -0.03 & 0.29 & 0.18 & 0.07 & 0.49 & 0.12 & 0.18 \\
\hline The division of labor between my co-workers and I is clear. & 0.10 & -0.08 & 0.17 & 0.17 & 0.18 & 0.09 & 0.72 & 0.16 & 0.08 & -0.03 & 0.08 & 0.12 & 0.07 & 0.03 & 0.53 & 0.06 \\
\hline The work division that I have to do is clearly identified. & 0.10 & -0.10 & 0.16 & 0.16 & 0.17 & 0.09 & 0.65 & 0.17 & 0.07 & -0.04 & 0.11 & 0.11 & 0.10 & 0.09 & 0.58 & 0.13 \\
\hline I have strong will to work hard in this company. & 0.11 & -0.07 & 0.15 & 0.18 & 0.18 & 0.09 & 0.09 & 0.71 & 0.11 & -0.09 & 0.15 & 0.12 & 0.15 & 0.09 & 0.05 & 0.72 \\
\hline I am willing to contribute to development of this company. & 0.10 & -0.11 & 0.19 & 0.19 & 0.20 & 0.08 & 0.07 & 0.65 & 0.07 & -0.09 & 0.17 & 0.16 & 0.19 & 0.08 & 0.02 & 0.67 \\
\hline I want to be employed by this company as long as possible. & 0.24 & -0.10 & 0.16 & 0.14 & 0.18 & 0.12 & 0.17 & 0.61 & 0.19 & -0.10 & 0.15 & 0.09 & 0.18 & 0.08 & 0.15 & 0.57 \\
\hline I have dreams about the future of my company and its work. & 0.26 & -0.09 & 0.19 & 0.15 & 0.18 & 0.17 & 0.11 & 0.59 & 0.19 & -0.07 & 0.19 & 0.15 & 0.15 & 0.15 & 0.10 & 0.64 \\
\hline My company makes very meaningulu contributions to this societ & 0.17 & -0.04 & 0.17 & 0.11 & 0.17 & 0.15 & 0.09 & 0.46 & 0.13 & -0.02 & 0.14 & 0.14 & 0.12 & 0.15 & 0.09 & 0.47 \\
\hline
\end{tabular}


Table 2. Descriptive statistics and correlations

\begin{tabular}{|c|c|c|c|c|c|c|c|c|c|c|c|c|c|c|c|c|c|c|c|c|}
\hline \multirow{2}{*}{ 2. } & \multicolumn{2}{|c|}{ Mean } & \multicolumn{2}{|c|}{$\mathrm{SD}$} & \multicolumn{16}{|c|}{ Non-graduatesI University graduates } \\
\hline & $\begin{array}{l}\text { University } \\
\text { graduates }\end{array}$ & $\begin{array}{c}\text { Non- } \\
\text { graduates }\end{array}$ & $\begin{array}{l}\text { University } \\
\text { graduates }\end{array}$ & $\begin{array}{c}\text { Non- } \\
\text { graduates }\end{array}$ & 1 & 2 & 3 & 4 & 5 & 6 & 7 & 8 & 9 & 10 & 11 & 12 & & 14 & 15 & \\
\hline 1 Gender & 0.604 & 0.512 & 0.489 & 0.500 & & $0.127^{\star *}$ & $0.038^{* \star}$ & 0.026 & $0.047^{\star \star}$ & $-0.080^{\star \star}$ & $0.125^{\star \star}$ & $0.032^{*}$ & -0.011 & $0.082^{\star \star}$ & $-0.035^{*}$ & $-0.043^{* *}$ & $0.062^{\star \star}$ & $0.056^{* *}$ & -0.023 & $-0.047^{\star \star}$ \\
\hline 2 Age & 31.076 & 29.217 & 6.228 & 6.720 & $0.113^{* *}$ & & $0.717^{\star \star}$ & $0.271^{* *}$ & $0.553^{* \star}$ & $0.039^{* \star}$ & $0.489^{* \star}$ & $0.192^{\star \star}$ & $0.088^{\star *}$ & $-0.074^{* *}$ & 0.013 & 0.015 & $0.259^{* *}$ & -0.005 & $0.128^{\star *}$ & $0.190^{* *}$ \\
\hline 3 Tenure & 5.192 & 5.730 & 4.922 & 5.243 & $-0.017^{\star}$ & $0.635^{* *}$ & & 0.026 & $0.483^{* *}$ & $-0.048^{* *}$ & $0.368^{* *}$ & $0.158^{\star \star}$ & 0.013 & -0.002 & -0.012 & 0.008 & $0.211^{\star *}$ & $-0.029^{*}$ & $0.107^{* *}$ & $0.116^{* *}$ \\
\hline 4 Turnover experience & 0.577 & 0.663 & 0.494 & 0.473 & $0.096^{* *}$ & $0.219^{\star *}$ & $-0.168^{*}$ & & $0.188^{\star \star}$ & $0.096^{\star \star}$ & $0.062^{* *}$ & $0.082^{\star \star}$ & 0.022 & $-0.091^{* *}$ & 0.001 & 0.006 & $0.081^{* *}$ & 0.001 & $0.068^{* *}$ & $0.094^{\star \star}$ \\
\hline 5 Marital s & 0.586 & 0.576 & 0.493 & 0.494 & $0.031^{* *}$ & $0.608^{* *}$ & $0.409^{* *}$ & $0.169^{* *}$ & & 0.011 & $0.239^{* *}$ & $0.155^{\star *}$ & 0.014 & -0.017 & -0.014 & 0.011 & $0.194^{\star \star}$ & $-0.035^{\star}$ & $0.102^{* *}$ & $0.118^{\star \star}$ \\
\hline 6 Indirect department & 0.837 & 0.359 & 0.370 & 0.480 & $0.047^{* *}$ & $0.123^{* *}$ & $0.076^{* *}$ & $0.036^{\star \star}$ & $0.025^{* *}$ & & 0.003 & $0.166^{* *}$ & $0.079^{* *}$ & $-0.091^{* *}$ & $0.052^{\star *}$ & $0.040^{\star *}$ & $0.046^{* *}$ & $0.050^{* *}$ & $0.059^{* *}$ & $0.076^{* *}$ \\
\hline 7 Position & 0.182 & 0.090 & 0.386 & 0.287 & $-0.071^{\star \star}$ & $0.163^{\star *}$ & $0.291^{* \star}$ & $-0.131^{\star * *}$ & $0.040^{\star \star}$ & $0.044^{\star \star}$ & 0.000 & -0.001 & $0.090^{\star \star}$ & -0.015 & 0.026 & $0.028^{*}$ & $0.157^{\star \star}$ & 0.024 & $0.058^{\star \star}$ & $0.117^{* *}$ \\
\hline 8 Year & 2012.189 & 2011.788 & 2.837 & 3.030 & $0.187^{\star *}$ & $0.249^{\star *}$ & $0.047^{* *}$ & $0.279^{\star *}$ & $0.202^{* *}$ & 0.003 & $-0.060^{* *}$ & & $0.224^{* *}$ & $-0.081^{* *}$ & $0.177^{\star \star}$ & $0.120^{\star *}$ & $0.208^{* *}$ & $0.212^{* *}$ & $0.181^{* *}$ & $0.240^{* *}$ \\
\hline 9 Benefit satisfaction & 3.147 & 2.948 & 0.934 & 0.969 & $0.067^{* *}$ & $0.150^{* *}$ & $0.045^{* *}$ & $0.086^{* \star}$ & $0.072^{* \star}$ & $0.089^{* *}$ & $0.039^{* *}$ & $0.190^{* *}$ & & $-0.281^{* *}$ & $0.500^{* *}$ & $0.378^{\star *}$ & $0.406^{* \star}$ & $0.542^{* *}$ & $0.334^{* *}$ & $0.542^{\star *}$ \\
\hline 10 Fatigue & $\begin{array}{l}3.181 \\
3.180\end{array}$ & $\begin{array}{l}2.940 \\
3.617\end{array}$ & 1.200 & 1.207 & $-0.018^{* *}$ & $-0.154^{* \star}$ & $\begin{array}{l}.0 .0599^{*} \\
-0\end{array}$ & $\begin{array}{l}0.000 \\
-0.058^{* *}\end{array}$ & $-0.091^{\star *}$ & $-0.149^{* *}$ & $0.018^{\star \star}$ & $-0.024^{* *}$ & $-0.342^{* *}$ & & $\begin{array}{l}-0.219^{* *} \\
\end{array}$ & $\begin{array}{l}0.203^{* *} \\
-0.0\end{array}$ & $\begin{array}{l}0.400 \\
-0.194^{* *}\end{array}$ & $=0.207^{* *}$ & $-0.217^{* *}$ & $\begin{array}{ll}* & -0.255^{\star *}\end{array}$ \\
\hline 11 Supe & 4.022 & 3.774 & 0.912 & 1.011 & 0.012 & $0.101^{* *}$ & $0.085^{* *}$ & -0.003 & $0.061^{* *}$ & $0.065^{* \star}$ & $0.070^{* *}$ & $0.046^{* *}$ & $0.498^{\star *}$ & $-0.256^{* *}$ & & $0.508^{\star \star}$ & $0.402^{\star \star}$ & $0.512^{* *}$ & $0.380^{* *}$ & $0.485^{* *}$ \\
\hline 13 Autonomy & 3. & 3.656 & 0.775 & 0.954 & $0.122^{\star \star}$ & $0.206^{* *}$ & $0.175^{* \star}$ & $0.029^{* *}$ & $0.147^{\star \star}$ & $0.106^{* \star}$ & $0.047^{* *}$ & $0.053^{* *}$ & $0.349^{* *}$ & $-0.224^{* *}$ & $0.343^{* *}$ & $0.352^{* *}$ & & $0.402^{* *}$ & $0.409^{* *}$ & $0.527^{\star *}$ \\
\hline 14 Training provision & 3.626 & 3.682 & 1.027 & 1.066 & $0.048^{\star *}$ & $0.087^{* *}$ & $0.047^{\star \star}$ & $0.030^{\star \star}$ & $0.058^{\star \star}$ & 0.007 & $0.053^{* *}$ & $0.124^{\star \star}$ & $0.489^{* *}$ & $-0.207^{\star *}$ & $0.498^{* *}$ & $0.428^{\star \star}$ & $0.386^{* *}$ & & $0.335^{* *}$ & $0.478^{* *}$ \\
\hline 15 Role clarity & 3.942 & 4.037 & 1.075 & 1.090 & $0.017^{\star \star}$ & $0.092^{* \star}$ & $0.048^{* \star}$ & $0.045^{\star \star}$ & $0.077^{\star \star}$ & $-0.022^{\star *}$ & 0.010 & $0.107^{\star \star}$ & $0.233^{\star *}$ & $-0.118^{* *}$ & $0.258^{\star *}$ & $0.316^{\star \star}$ & $0.216^{* \star}$ & $0.245^{\star \star}$ & & $0.419^{* \star}$ \\
\hline 16 Organizational commitment & 4.047 & 4.030 & 0.810 & 0.865 & $-0.051^{* *}$ & $0.218^{* *}$ & $0.178^{* \star}$ & $0.019^{* *}$ & $0.142^{* *}$ & $0.057^{* \star}$ & $0.132^{* *}$ & $0.026^{* *}$ & $0.466^{* *}$ & $-0.254^{* *}$ & $0.470^{* *}$ & $0.459^{* *}$ & $0.429^{* *}$ & $0.458^{* *}$ & $0.267^{* *}$ & \\
\hline
\end{tabular}

Note: $n=5,166$ (University graduates), 22,688(Non-graduates). ${ }^{* *} p<0.01,{ }^{*} p<0.05$.

Correlations for University graduates appear above diagonal and Non-graduates below diagonal. 
Table 3. Results of hierarchical regression analyses.

Organizational commitment

(University graduates and Non-graduates, $n=27,854$ )

\begin{tabular}{|c|c|c|c|c|c|c|c|c|c|c|c|}
\hline Variables & Step 1 & \multicolumn{2}{|c|}{ Step 2} & \multicolumn{2}{|c|}{ Step 3} & \multicolumn{2}{|c|}{ Step 4} & \multicolumn{2}{|l|}{ Step 5} & \multicolumn{2}{|c|}{ Step 6} \\
\hline Gender & $-0.07^{* *}$ & -0.07 & ** & -0.05 & ** & $-0.10^{*}$ & ** & -0.08 * & ** & -0.08 & ** \\
\hline Age & $0.17 * *$ & 0.08 & $* *$ & 0.12 & ** & 0.12 * & ** & 0.08 * & ** & 0.09 & ** \\
\hline Tenure & 0.00 & 0.04 & ** & 0.01 & & $-0.01 *$ & * & 0.01 & & 0.00 & \\
\hline Turnover experience & $0.02 *$ & 0.02 & $* *$ & 0.03 & ** & 0.02 * & ** & 0.02 * & ** & 0.02 & ** \\
\hline Marital status & $0.02 * *$ & 0.04 & ** & 0.02 & ** & 0.01 & & 0.02 * & ** & 0.02 & ** \\
\hline Indirect department & $0.02 * *$ & -0.03 & $* *$ & -0.01 & & 0.01 & & $-0.03 *$ & ** & -0.01 & * \\
\hline Position & $0.04 * *$ & 0.01 & * & 0.03 & ** & $0.03 *$ & ** & 0.02 * & ** & 0.02 & ** \\
\hline Northeast & $0.17 * *$ & 0.18 & $* *$ & 0.12 & ** & 0.13 * & ** & 0.14 * & ** & 0.14 & ** \\
\hline North & $0.07^{* *}$ & 0.08 & ** & 0.04 & ** & 0.07 * & ** & 0.06 * & ** & 0.07 & ** \\
\hline East & $0.04^{* *}$ & 0.02 & $* *$ & 0.00 & & 0.02 * & ** & 0.01 & & 0.01 & \\
\hline Year & $0.08 * *$ & 0.01 & & 0.04 & ** & 0.01 * & * & 0.00 & & 0.01 & \\
\hline \multicolumn{12}{|l|}{ Extrinsic rewards } \\
\hline Benefit satisfaction & & 0.44 & $* *$ & & & & & 0.20 * & ** & 0.19 & ** \\
\hline Fatigue & & -0.10 & $* *$ & & & & & $-0.05 *$ & ** & -0.05 & ** \\
\hline \multicolumn{12}{|l|}{ Social rewards } \\
\hline Supervisor support & & & & 0.31 & ** & & & 0.12 * & ** & 0.13 & ** \\
\hline Co-worker support & & & & 0.30 & ** & & & 0.18 * & ** & 0.17 & ** \\
\hline \multicolumn{12}{|l|}{ Intrinsic rewards } \\
\hline Autonomy & & & & & & 0.28 * & ** & 0.18 * & ** & 0.18 & ** \\
\hline Training provision & & & & & & 0.31 * & ** & 0.12 * & ** & 0.12 & $* *$ \\
\hline Role clarity & & & & & & 0.13 * & ** & 0.06 * & ** & 0.05 & ** \\
\hline Sample & & & & & & & & & & -0.18 & ** \\
\hline Sample×Benefit satisfaction & & & & & & & & & & 0.05 & ** \\
\hline Sample×Fatigue & & & & & & & & & & 0.01 & \\
\hline Sample×Supervisor support & & & & & & & & & & -0.05 & * \\
\hline Sample×Co-worker support & & & & & & & & & & 0.02 & \\
\hline Sample×Autonomy & & & & & & & & & & 0.08 & ** \\
\hline Sample×Training provision & & & & & & & & & & -0.02 & \\
\hline Sample×Role Clarity & & & & & & & & & & 0.05 & * \\
\hline$R^{2}$ & 0.08 & 0.30 & & 0.34 & & 0.35 & & 0.45 & & 0.45 & \\
\hline Adjusted $\mathrm{R}^{2}$ & 0.08 & 0.30 & & 0.34 & & 0.35 & & 0.45 & & 0.45 & \\
\hline $\mathrm{F}$ & $209.30 * *$ & 899.82 & ** & 1115.01 & ** & 1093.91 * & ** & $1244.02 *$ & ** & 870.61 & ** \\
\hline
\end{tabular}

${ }^{*}$ Significance at the $5 \%$ level; ${ }^{* *}$ Significance at the $1 \%$ level. 
Table3. Results of hierarchical regression analyses (continued).

\begin{tabular}{|c|c|c|c|c|c|}
\hline \multirow[b]{2}{*}{ Variables } & \multicolumn{5}{|c|}{$\begin{array}{l}\text { Organizational commitment } \\
\text { (University graduates, } n=5,166)\end{array}$} \\
\hline & Step 1 & Step 2 & Step 3 & Step 4 & Step 5 \\
\hline Gender & $-0.07 * *$ & $-0.04^{* *}$ & $-0.04^{* *}$ & -0.09 ** & $-0.06 *$ \\
\hline Age & $0.15^{* *}$ & $0.08 * *$ & $0.15^{* *}$ & $0.10^{* *}$ & $0.09 *$ \\
\hline Tenure & $-0.05 * *$ & 0.01 & -0.03 & -0.06 ** & -0.02 \\
\hline Turnover experience & $0.04 * *$ & $0.05^{* *}$ & $0.05^{* *}$ & $0.03 * *$ & 0.04 * \\
\hline Marital status & 0.01 & $0.03 *$ & 0.02 & 0.00 & 0.01 \\
\hline Indirect department & 0.01 & -0.01 & 0.01 & 0.00 & 0.00 \\
\hline Position & $0.05^{* *}$ & 0.01 & $0.03 *$ & 0.02 & 0.01 \\
\hline Northeast & $0.18^{* *}$ & $0.14^{* *}$ & $0.13^{* *}$ & $0.11^{* *}$ & 0.11 * \\
\hline North & $0.05 *$ & 0.05 ** & $0.05^{* *}$ & $0.05 * *$ & 0.05 * \\
\hline East & 0.06 ** & 0.03 & 0.06 ** & $0.05 * *$ & 0.04 * \\
\hline Year & 0.23 ** & 0.12 ** & $0.13^{* *}$ & $0.09 * *$ & 0.07 * \\
\hline \multicolumn{6}{|l|}{ Extrinsic rewards } \\
\hline Benefit satisfaction & & $0.47^{* *}$ & & & 0.23 * \\
\hline Fatigue & & $-0.10^{* *}$ & & & $-0.04 *$ \\
\hline \multicolumn{6}{|l|}{ Social rewards } \\
\hline Supervisor support & & & 0.28 ** & & 0.09 * \\
\hline Co-worker support & & & $0.33^{* *}$ & & 0.18 * \\
\hline \multicolumn{6}{|l|}{ Intrinsic rewards } \\
\hline Autonomy & & & & $0.31^{* *}$ & 0.20 * \\
\hline Training provision & & & & $0.28 * *$ & 0.10 * \\
\hline Role clarity & & & & $0.17^{* *}$ & 0.08 * \\
\hline \multicolumn{6}{|l|}{ Sample } \\
\hline \multicolumn{6}{|c|}{ Sample×Benefit satisfaction } \\
\hline \multicolumn{6}{|c|}{ Sample×Fatigue } \\
\hline \multicolumn{6}{|c|}{ Sample×Supervisor support } \\
\hline \multirow{2}{*}{\multicolumn{6}{|c|}{ Sample×Co-worker support }} \\
\hline \multicolumn{3}{|l|}{ SamplexAutonomy } & & & \\
\hline \multirow{2}{*}{\multicolumn{6}{|c|}{$\begin{array}{l}\text { Sample×Training provision } \\
\text { Sample×Role Clarity }\end{array}$}} \\
\hline & & & & & \\
\hline $\mathrm{R}^{2}$ & 0.11 & 0.35 & 0.38 & 0.42 & 0.50 \\
\hline Adjusted $\mathrm{R}^{2}$ & 0.11 & 0.35 & 0.38 & 0.42 & 0.50 \\
\hline $\mathrm{F}$ & $57.62^{* *}$ & $214.21^{* *}$ & 247.05 ** & 264.78 ** & $288.20 *$ \\
\hline
\end{tabular}

${ }^{*}$ Significance at the $5 \%$ level; **Significance at the $1 \%$ level.

\begin{tabular}{|c|c|c|c|c|}
\hline \multicolumn{5}{|c|}{$\begin{array}{l}\text { Organizational commitment } \\
\text { (Non-graduates, } n=22,688 \text { ) }\end{array}$} \\
\hline Step 1 & Step 2 & Step 3 & Step 4 & Step 5 \\
\hline-0.06 ** & -0.07 ** & -0.05 ** & $-0.10^{* *}$ & $-0.08^{* *}$ \\
\hline $0.18^{* *}$ & $0.10^{* *}$ & $0.14^{* *}$ & $0.13^{* *}$ & $0.10^{* *}$ \\
\hline 0.00 & $0.02 *$ & 0.00 & $-0.02 * *$ & -0.01 \\
\hline 0.01 & 0.01 & 0.02 ** & 0.01 & 0.01 * \\
\hline $0.03^{* *}$ & $0.04^{* \star}$ & 0.02 ** & 0.01 & 0.02 ** \\
\hline $0.03^{* *}$ & $-0.02^{* *}$ & 0.01 & $0.01 *$ & -0.01 ** \\
\hline $0.05^{* *}$ & 0.02 ** & $0.03 * *$ & $0.03 * *$ & $0.03^{* *}$ \\
\hline $0.17^{* *}$ & $0.19^{* \star}$ & $0.11^{* *}$ & $0.14^{* *}$ & $0.14^{* *}$ \\
\hline $0.08^{* *}$ & $0.09^{* \star}$ & $0.05^{* *}$ & $0.08^{* *}$ & $0.07^{* *}$ \\
\hline $0.03^{* *}$ & $0.02^{* \star}$ & -0.01 & $0.01 *$ & 0.00 \\
\hline \multirow[t]{8}{*}{0.04 ** } & -0.01 & 0.02 ** & 0.00 & 0.00 \\
\hline & $0.43^{* *}$ & & & $0.19^{* *}$ \\
\hline & -0.10 ** & & & $-0.05^{* *}$ \\
\hline & & $0.31^{* *}$ & & $0.13^{* *}$ \\
\hline & & $0.30^{* *}$ & & $0.17^{* *}$ \\
\hline & & & $0.27 * *$ & $0.18^{* *}$ \\
\hline & & & $0.31 * *$ & $0.12^{* *}$ \\
\hline & & & $0.12 * *$ & $0.05^{* *}$ \\
\hline
\end{tabular}


Appendix. Demographic information.

\begin{tabular}{c|c|c|c|c|c|c|c|c|c}
\hline & \multicolumn{7}{c|}{ Educational background } & \multirow{2}{*}{ Total } \\
\cline { 2 - 9 } & $\begin{array}{c}\text { Lower } \\
\text { Secondary } \\
\text { School }\end{array}$ & $\begin{array}{c}\text { Upper } \\
\text { Secondary } \\
\text { School }\end{array}$ & $\begin{array}{c}\text { Specialized } \\
\text { College }\end{array}$ & $\begin{array}{c}\text { College/ } \\
\text { Vocational }\end{array}$ & University & $\begin{array}{c}\text { Graduate } \\
\text { School }\end{array}$ & $\begin{array}{c}\text { In the middle } \\
\text { of school } \\
\text { years }\end{array}$ & Others & \\
\hline University & 0 & 0 & 0 & 0 & 4,795 & 372 & 0 & 0 & 5,166 \\
graduates & $0.0 \%$ & $0.0 \%$ & $0.0 \%$ & $0.0 \%$ & $92.8 \%$ & $7.2 \%$ & $0.0 \%$ & $0.0 \%$ & $100.0 \%$ \\
\hline Non- & 4,642 & 4,517 & 7,486 & 5,786 & 0 & 0 & 118 & 139 & 22,688 \\
graduates & $20.5 \%$ & $19.9 \%$ & $33.0 \%$ & $25.5 \%$ & $0.0 \%$ & $0.0 \%$ & $0.5 \%$ & $0.6 \%$ & $100.0 \%$ \\
\hline Total & 4,642 & 4,517 & 7,486 & 5,786 & 4,794 & 372 & 118 & 139 & 27,854 \\
& $16.7 \%$ & $16.2 \%$ & $26.9 \%$ & $20.8 \%$ & $17.2 \%$ & $1.3 \%$ & $0.4 \%$ & $0.5 \%$ & $100.0 \%$ \\
\hline
\end{tabular}

\begin{tabular}{|c|c|c|c|c|c|c|c|c|c|}
\hline & \multicolumn{2}{|c|}{ Gender } & \multirow{2}{*}{ Total } & \multicolumn{5}{|c|}{ Age } & \multirow{2}{*}{ Total } \\
\hline & Male & Female & & $\begin{array}{l}\text { Below } 20 \\
\text { years old }\end{array}$ & $20-29$ & $30-39$ & 40-49 & $\begin{array}{c}50 \text { years old } \\
\text { and above }\end{array}$ & \\
\hline $\begin{array}{l}\text { University } \\
\text { graduates }\end{array}$ & $\begin{array}{l}3,119 \\
60.4 \%\end{array}$ & $\begin{array}{l}2,047 \\
39.6 \%\end{array}$ & $\begin{array}{c}5,166 \\
100.0 \%\end{array}$ & $\begin{array}{c}1 \\
0.0 \%\end{array}$ & $\begin{array}{l}2,444 \\
47.3 \%\end{array}$ & $\begin{array}{l}2,192 \\
42.4 \%\end{array}$ & $\begin{array}{l}457 \\
8.8 \%\end{array}$ & $\begin{array}{c}72 \\
1.4 \%\end{array}$ & $\begin{array}{c}5,166 \\
100.0 \%\end{array}$ \\
\hline $\begin{array}{c}\text { Non- } \\
\text { graduates }\end{array}$ & $\begin{array}{c}11,621 \\
51.2 \%\end{array}$ & $\begin{array}{r}11,067 \\
48.8 \%\end{array}$ & $\begin{array}{l}22,688 \\
100.0 \%\end{array}$ & $\begin{array}{l}875 \\
3.9 \%\end{array}$ & $\begin{array}{r}11,747 \\
51.8 \%\end{array}$ & $\begin{array}{l}8,399 \\
37.0 \%\end{array}$ & $\begin{array}{c}1,492 \\
6.6 \%\end{array}$ & $\begin{array}{l}175 \\
0.8 \%\end{array}$ & $\begin{array}{l}22,688 \\
100.0 \%\end{array}$ \\
\hline \multirow[t]{3}{*}{ Total } & $\begin{array}{r}14,740 \\
52.9 \% \\
\end{array}$ & $\begin{array}{r}13,114 \\
47.1 \% \\
\end{array}$ & $\begin{array}{l}27,854 \\
100.0 \% \\
\end{array}$ & $\begin{array}{l}876 \\
3.1 \% \\
\end{array}$ & $\begin{array}{r}14,191 \\
50.9 \% \\
\end{array}$ & $\begin{array}{r}10,591 \\
38.0 \% \\
\end{array}$ & $\begin{array}{r}1,949 \\
7.0 \% \\
\end{array}$ & $\begin{array}{c}247 \\
0.9 \% \\
\end{array}$ & $\begin{array}{l}27,854 \\
100.0 \% \\
\end{array}$ \\
\hline & \multicolumn{5}{|c|}{ Tenure } & \multirow{2}{*}{ Total } & \multicolumn{2}{|c|}{ Turnover experience } & \multirow{2}{*}{ Total } \\
\hline & $\begin{array}{c}\text { Below } 1 \\
\text { year }\end{array}$ & 1 year & $2-4$ years & $5-9$ years & $\begin{array}{c}10 \text { years and } \\
\text { above }\end{array}$ & & $\begin{array}{c}\text { Have } \\
\text { experience }\end{array}$ & $\begin{array}{c}\text { Have no } \\
\text { experience }\end{array}$ & \\
\hline $\begin{array}{r}\text { University } \\
\text { graduates }\end{array}$ & $\begin{array}{c}705 \\
13.6 \% \\
\end{array}$ & $\begin{array}{c}744 \\
14.4 \% \\
\end{array}$ & $\begin{array}{l}1,443 \\
27.9 \% \\
\end{array}$ & $\begin{array}{l}1,313 \\
25.4 \% \\
\end{array}$ & $\begin{array}{c}961 \\
18.6 \% \\
\end{array}$ & $\begin{array}{c}5,166 \\
100.0 \% \\
\end{array}$ & $\begin{array}{l}2,982 \\
57.7 \% \\
\end{array}$ & $\begin{array}{l}2,184 \\
42.3 \% \\
\end{array}$ & $\begin{array}{c}5,166 \\
100.0 \% \\
\end{array}$ \\
\hline $\begin{array}{c}\text { Non- } \\
\text { graduates }\end{array}$ & $\begin{array}{l}2,277 \\
10.0 \%\end{array}$ & $\begin{array}{l}2,901 \\
12.8 \%\end{array}$ & $\begin{array}{l}6,533 \\
28.8 \%\end{array}$ & $\begin{array}{l}6,227 \\
27.4 \%\end{array}$ & $\begin{array}{l}4,750 \\
20.9 \% \\
\end{array}$ & $\begin{array}{l}22,688 \\
100.0 \%\end{array}$ & $\begin{array}{c}15,036 \\
66.3 \%\end{array}$ & $\begin{array}{l}7,652 \\
33.7 \%\end{array}$ & $\begin{array}{l}22,688 \\
100.0 \%\end{array}$ \\
\hline Total & $\begin{array}{l}2,982 \\
10.7 \%\end{array}$ & $\begin{array}{l}3,645 \\
13.1 \%\end{array}$ & $\begin{array}{l}7,976 \\
28.6 \%\end{array}$ & $\begin{array}{l}7,540 \\
27.1 \%\end{array}$ & $\begin{array}{l}5,711 \\
20.5 \%\end{array}$ & $\begin{array}{l}27,854 \\
100.0 \%\end{array}$ & $\begin{array}{r}18,018 \\
64.7 \%\end{array}$ & $\begin{array}{l}9,836 \\
35.3 \%\end{array}$ & $\begin{array}{l}27,854 \\
100.0 \%\end{array}$ \\
\hline
\end{tabular}

\begin{tabular}{|c|c|c|c|c|c|c|c|c|c|c|}
\hline & \multicolumn{3}{|c|}{ Marital status } & \multirow[b]{2}{*}{ Total } & \multicolumn{2}{|c|}{ Indirect department } & \multirow[b]{2}{*}{ Total } & \multicolumn{2}{|c|}{ Position } & \multirow[b]{2}{*}{ Total } \\
\hline & Single & Married & Others & & $\begin{array}{c}\text { Direct } \\
\text { department }\end{array}$ & $\begin{array}{l}\text { Indirect } \\
\text { department }\end{array}$ & & $\begin{array}{c}\text { Managerial } \\
\text { position }\end{array}$ & $\begin{array}{c}\text { Non- } \\
\text { managerial } \\
\text { position }\end{array}$ & \\
\hline $\begin{array}{l}\text { University } \\
\text { graduates }\end{array}$ & $\begin{array}{l}1,980 \\
38.3 \% \\
\end{array}$ & $\begin{array}{l}3,025 \\
58.6 \% \\
\end{array}$ & $\begin{array}{c}161 \\
3.1 \% \\
\end{array}$ & $\begin{array}{c}5,166 \\
100.0 \% \\
\end{array}$ & $\begin{array}{c}844 \\
16.3 \% \\
\end{array}$ & $\begin{array}{l}4,322 \\
83.7 \% \\
\end{array}$ & $\begin{array}{c}5,166 \\
100.0 \% \\
\end{array}$ & $\begin{array}{c}940 \\
18.2 \% \\
\end{array}$ & $\begin{array}{l}4,226 \\
81.8 \% \\
\end{array}$ & $\begin{array}{c}5,166 \\
100.0 \% \\
\end{array}$ \\
\hline $\begin{array}{c}\begin{array}{c}\text { Non- } \\
\text { graduates }\end{array} \\
\end{array}$ & $\begin{array}{l}8,199 \\
36.1 \% \\
\end{array}$ & $\begin{array}{r}13,062 \\
57.6 \% \\
\end{array}$ & $\begin{array}{r}1,427 \\
6.3 \% \\
\end{array}$ & $\begin{array}{l}22,688 \\
100.0 \% \\
\end{array}$ & $\begin{array}{r}14,532 \\
64.1 \% \\
\end{array}$ & $\begin{array}{l}8,156 \\
35.9 \% \\
\end{array}$ & $\begin{array}{l}22,688 \\
100.0 \% \\
\end{array}$ & $\begin{array}{r}2,049 \\
9.0 \% \\
\end{array}$ & $\begin{array}{r}20,639 \\
91.0 \% \\
\end{array}$ & $\begin{array}{l}22,688 \\
100.0 \% \\
1\end{array}$ \\
\hline Total & $\begin{array}{l}10,179 \\
36.5 \% \\
\end{array}$ & $\begin{array}{r}16,087 \\
57.8 \% \\
\end{array}$ & $\begin{array}{r}1,588 \\
5.7 \% \\
\end{array}$ & $\begin{array}{l}27,854 \\
100.0 \% \\
\end{array}$ & $\begin{array}{r}15,376 \\
55.2 \% \\
\end{array}$ & $\begin{array}{r}12,478 \\
44.8 \% \\
\end{array}$ & $\begin{array}{l}27,854 \\
100.0 \% \\
\end{array}$ & $\begin{array}{l}2,989 \\
10.7 \% \\
\end{array}$ & $\begin{array}{r}24,865 \\
89.3 \% \\
\end{array}$ & $\begin{array}{l}27,854 \\
100.0 \% \\
\end{array}$ \\
\hline
\end{tabular}

\begin{tabular}{c|c|c|c|c|c}
\hline \multirow{2}{*}{} & \multicolumn{4}{|c|}{ Area } & \multirow{2}{*}{ Total } \\
\cline { 2 - 5 } & \multirow{2}{*}{ Northeast } & North & East & South & \\
\hline University & 1,204 & 1,058 & 2,292 & 612 & 5,166 \\
graduates & $23.3 \%$ & $20.5 \%$ & $44.4 \%$ & $11.8 \%$ & $100.0 \%$ \\
\hline $\begin{array}{c}\text { Non- } \\
\text { graduates }\end{array}$ & 4,853 & 3,886 & 8,936 & 5,013 & 22,688 \\
\hline Total & 6,057 & $17.1 \%$ & $39.4 \%$ & $22.1 \%$ & $100.0 \%$ \\
\hline
\end{tabular}

\begin{tabular}{c|c|c|c|c|c|c|c|c|c|c|c}
\hline & \multicolumn{10}{|c|}{ Year } & \multirow{2}{*}{ Total } \\
\cline { 2 - 12 } & 2007 & 2008 & 2009 & 2010 & 2011 & 2012 & 2013 & 2014 & 2015 & 2016 & \\
\hline University & 429 & 614 & 228 & 10 & 831 & 151 & 24 & 1,591 & 1,244 & 44 & 5,166 \\
graduates & $8.3 \%$ & $11.9 \%$ & $4.4 \%$ & $0.2 \%$ & $16.1 \%$ & $2.9 \%$ & $0.5 \%$ & $30.8 \%$ & $24.1 \%$ & $0.9 \%$ & $100.0 \%$ \\
\hline $\begin{array}{c}\text { Non- } \\
\text { graduates }\end{array}$ & 3,093 & 2,028 & 1,469 & 131 & 5,092 & 238 & 636 & 2,365 & 7,372 & 264 & 22,688 \\
\hline Total & 3,522 & $8.9 \%$ & $6.5 \%$ & $0.6 \%$ & $22.4 \%$ & $1.0 \%$ & $2.8 \%$ & $10.4 \%$ & $32.5 \%$ & $1.2 \%$ & $100.0 \%$ \\
\hline
\end{tabular}

